\title{
LEVEL II SCOUR ANALYSIS FOR BRIDGE 80 (JAMAVT01000080) on STATE ROUTE 100, crossing the WEST RIVER, JAMAICA, VERMONT
}

U.S. Geological Survey Open-File Report 97-214

Prepared in cooperation with

VERMONT AGENCY OF TRANSPORTATION and

FEDERAL HIGHWAY ADMINISTRATION 


\section{LEVEL II SCOUR ANALYSIS FOR BRIDGE 80 (JAMAVT01000080) on STATE ROUTE 100, crossing the WEST RIVER, JAMAICA, VERMONT}

By MICHAEL A. IVANOFF \& JAMES R. DEGNAN

U.S. Geological Survey Open-File Report 97-214

Prepared in cooperation with

VERMONT AGENCY OF TRANSPORTATION

and

FEDERAL HIGHWAY ADMINISTRATION 


\title{
U.S. DEPARTMENT OF THE INTERIOR BRUCE BABBITT, Secretary
}

\author{
U.S. GEOLOGICAL SURVEY \\ Gordon P. Eaton, Director
}

For additional information write to:

District Chief

U.S. Geological Survey 361 Commerce Way

Pembroke, NH 03275-3718
Copies of this report may be purchased from:

U.S. Geological Survey

Branch of Information Services

Open-File Reports Unit

Box 25286

Denver, CO 80225-0286 


\section{CONTENTS}

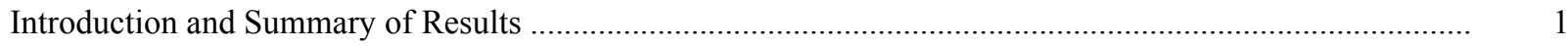

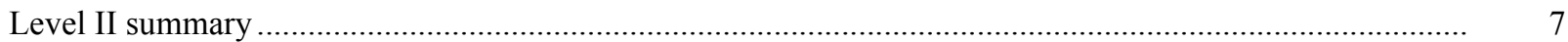

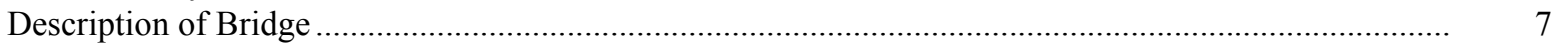

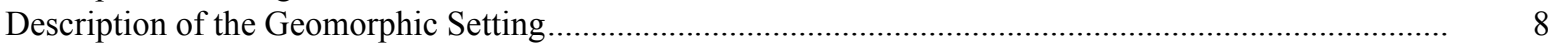

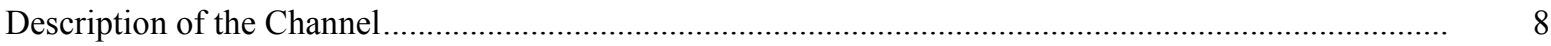

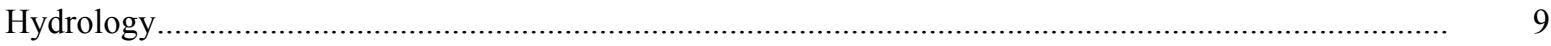

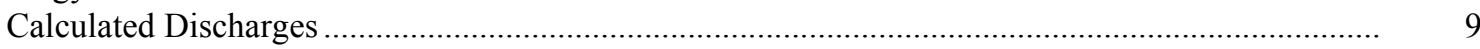

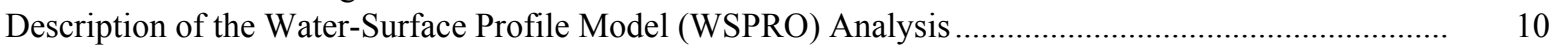

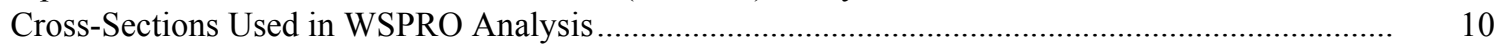

Data and Assumptions Used in WSPRO Model ...................................................................... 11

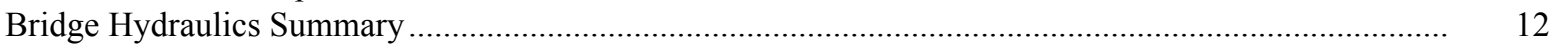

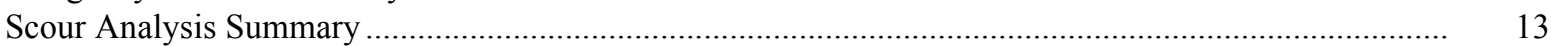

Special Conditions or Assumptions Made in Scour Analysis ...................................................... 13

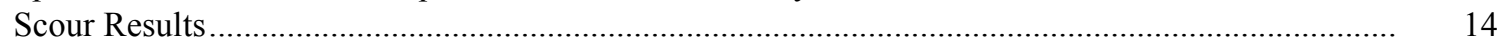

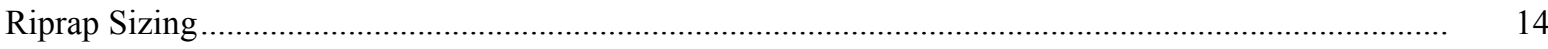

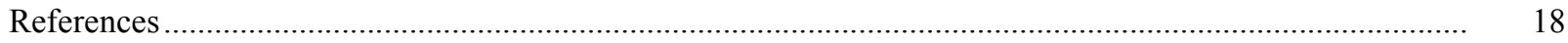

Appendixes:

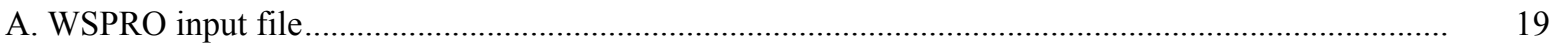

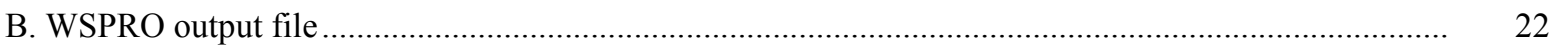

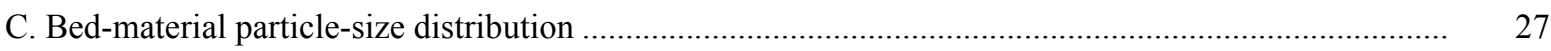

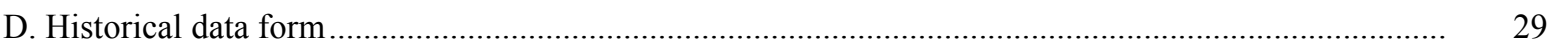

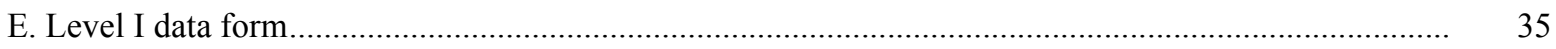

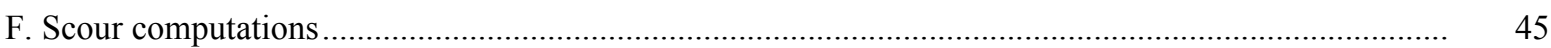

\section{FIGURES}

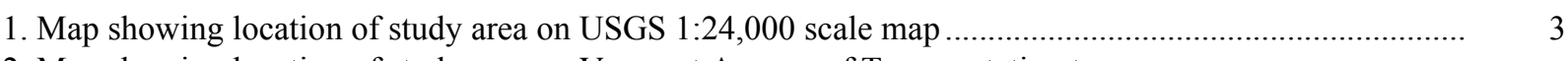

2. Map showing location of study area on Vermont Agency of Transportation town
highway map

3. Structure JAMAVT01000080 viewed from upstream (August 13, 1996) .............................................. 5

4. Downstream channel viewed from structure JAMAVT01000080 (August 13, 1996)............................ 5

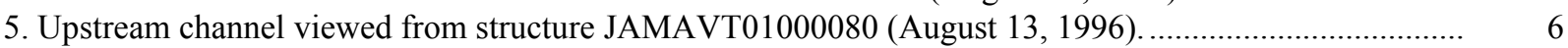

6. Structure JAMAVT01000080 viewed from downstream (August 13, 1996)........................................ 6

7. Water-surface profiles for the 100- and 500-year discharges at structure JAMAVT01000080 on State Route 100, crossing the West River,

Jamaica, Vermont.

8. Scour elevations for the 100- and 500-year discharges at structure

JAMAVT01000080 on State Route 100, crossing the West River,

Jamaica, Vermont.

(3)

5

5

(1)

6

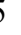

\section{TABLES}

1. Remaining footing/pile depth at abutments for the 100-year discharge at structure

JAMAVT01000080 on State Route 100, crossing the West River,

Jamaica, Vermont.

2. Remaining footing/pile depth at abutments for the 500-year discharge at structure

JAMAVT01000080 on State Route 100, crossing the West River,

Jamaica, Vermont. 


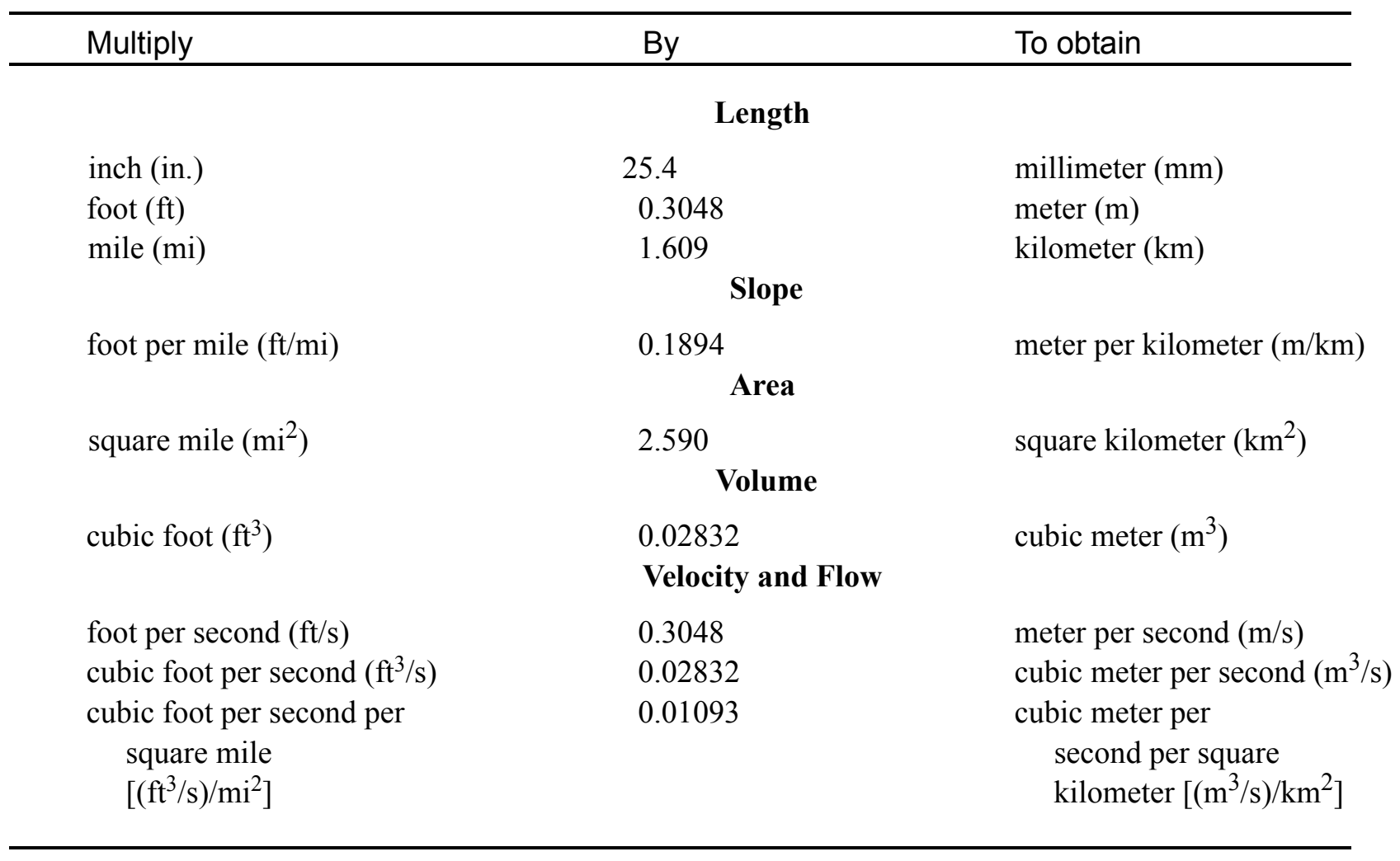

\section{OTHER ABBREVIATIONS}

$\begin{array}{lrlr}\mathrm{BF} & \text { bank full } & \text { LWW } & \text { left wingwall } \\ \mathrm{cfs} & \text { cubic feet per second } & \text { MC } & \text { main channel } \\ \mathrm{D}_{50} & \text { median diameter of bed material } & \text { RAB } & \text { right abutment } \\ \mathrm{DS} & \text { downstream } & \text { RABUT } & \text { face of right abutment } \\ \mathrm{elev} & \text { elevation } & \text { RB } & \text { right bank } \\ \mathrm{f} / \mathrm{p} & \text { flood plain } & \text { ROB } & \text { right overbank } \\ \mathrm{ft}^{2} & \text { square feet } & \text { RWW } & \text { right wingwall } \\ \mathrm{ft} / \mathrm{ft} & \text { feet per foot } & \text { TH } & \text { town highway } \\ \mathrm{JCT} & \text { junction } & \text { UB } & \text { under bridge } \\ \mathrm{LAB} & \text { left abutment } & \text { US } & \text { upstream } \\ \mathrm{LABUT} & \text { face of left abutment } & \text { USGS } & \text { United States Geological Survey } \\ \mathrm{LB} & \text { left bank } & \text { VTAOT Vermont Agency of Transportation } \\ \mathrm{LOB} & \text { left overbank } & \text { WSPRO } & \text { water-surface profile model }\end{array}$

In this report, the words "right" and "left" refer to directions that would be reported by an observer facing downstream. Sea level: In this report, "sea level" refers to the National Geodetic Vertical Datum of 1929-- a geodetic datum derived from a general adjustment of the first-order level nets of the United States and Canada, formerly called Sea Level Datum of 1929.

In the appendices, the above abbreviations may be combined. For example, USLB would represent upstream left bank. 


\title{
LEVEL II SCOUR ANALYSIS FOR BRIDGE 80 (JAMAVT01000080) ON STATE ROUTE 100, CROSSING THE WEST RIVER, JAMAICA, VERMONT
}

\author{
By Michael A. Ivanoff and James R. Degnan
}

\section{INTRODUCTION AND SUMMARY OF RESULTS}

This report provides the results of a detailed Level II analysis of scour potential at structure JAMAVT01000080 on State Route 100 crossing the West River, Jamaica, Vermont (figures 1-8). A Level II study is a basic engineering analysis of the site, including a quantitative analysis of stream stability and scour (U.S. Department of Transportation, 1993). Results of a Level I scour investigation also are included in Appendix E of this report. A Level I investigation provides a qualitative geomorphic characterization of the study site. Information on the bridge, gleaned from Vermont Agency of Transportation (VTAOT) files, was compiled prior to conducting Level I and Level II analyses and is found in Appendix D.

The site is in the Green Mountain section of the New England physiographic province in southern Vermont. The $227-\mathrm{mi}^{2}$ drainage area is in a predominantly rural and forested basin. In the vicinity of the study site, the surface cover is pasture on the upstream left bank and downstream of the bridge while the immediate banks have dense woody vegetation. The upstream right bank of the bridge is forested.

In the study area, the West River has an incised, straight channel with a slope of approximately $0.01 \mathrm{ft} / \mathrm{ft}$, an average channel top width of $309 \mathrm{ft}$ and an average bank height of $10 \mathrm{ft}$. The channel bed material is predominantly cobble with a median grain size $\left(\mathrm{D}_{50}\right)$ of $109 \mathrm{~mm}(0.359 \mathrm{ft})$. The geomorphic assessment at the time of the Level I and Level II site visit on August 13, 1996, indicated that the reach was stable.

The State Route 100 crossing of the West River is a 246-ft-long, one-lane steel thru-truss bridge consisting of three spans, the longest is 161-feet (Vermont Agency of Transportation, written communication, March 30, 1995). The bridge is supported by vertical, concrete abutments and two piers. The channel is skewed approximately 5 degrees to the opening while there is no opening-skew-to-roadway. 
A scour hole $3 \mathrm{ft}$ deeper than the mean thalweg depth was observed along the streamward (right) side of the left pier during the Level I assessment. A scour hole $5 \mathrm{ft}$ deeper than the mean thalweg depth was observed along the streamward (left) side of the right pier during the Level I assessment. The only scour protection measure at the site was type-2 stone fill (less than 36 inches diameter) along the left and right bank below the abutments forming a "spill-through" slope at each abutment. Additional details describing conditions at the site are included in the Level II Summary and Appendices D and E.

Scour depths and recommended rock rip-rap sizes were computed using the general guidelines described in Hydraulic Engineering Circular 18 (Richardson and others, 1995). Total scour at a highway crossing is comprised of three components: 1) long-term streambed degradation; 2) contraction scour (due to accelerated flow caused by a reduction in flow area at a bridge) and; 3 ) local scour (caused by accelerated flow around piers and abutments). Total scour is the sum of the three components. Equations are available to compute depths for contraction and local scour and a summary of the results of these computations follows.

There was no computed contraction scour. Abutment scour ranged from 15.8 to $23.9 \mathrm{ft}$. The worst-case abutment scour occurred at the 500-year discharge. Pier scour ranged from 9.5 to $22.8 \mathrm{ft}$. The worst-case pier scour occurred at the 500-year discharge. Additional information on scour depths and depths to armoring are included in the section titled "Scour Results". Scoured-streambed elevations, based on the calculated scour depths, are presented in tables 1 and 2. A cross-section of the scour computed at the bridge is presented in figure 8. Scour depths were calculated assuming an infinite depth of erosive material and a homogeneous particle-size distribution.

It is generally accepted that the Froehlich equation (abutment scour) gives "excessively conservative estimates of scour depths" (Richardson and others, 1995, p. 47). Usually, computed scour depths are evaluated in combination with other information including (but not limited to) historical performance during flood events, the geomorphic stability assessment, existing scour protection measures, and the results of the hydraulic analyses. Therefore, scour depths adopted by VTAOT may differ from the computed values documented herein. 


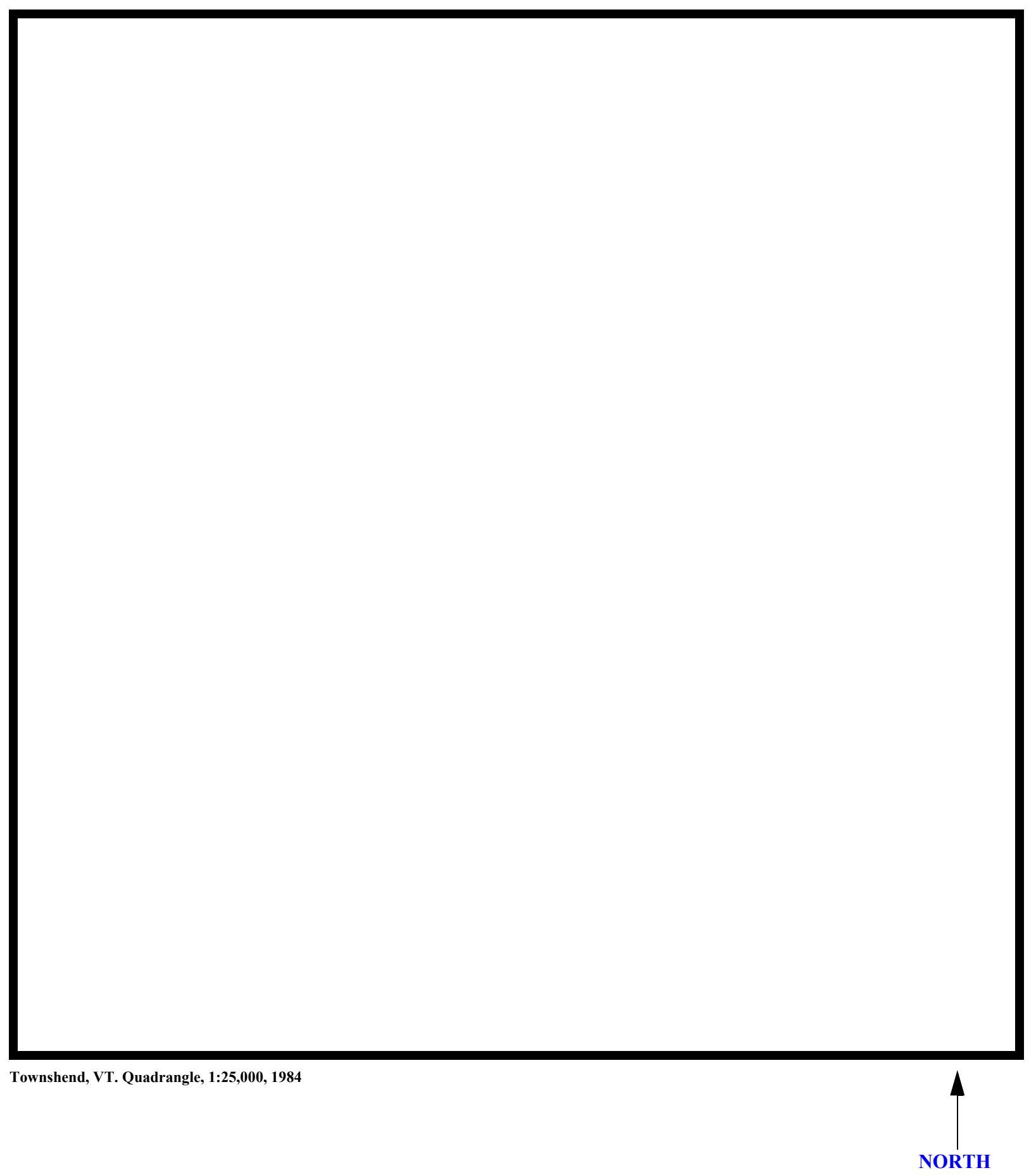

Figure 1. Location of study area on USGS 1:24,000 scale map. 
Figure 2. Location of study area on Vermont Agency of Transportation town highway map. 

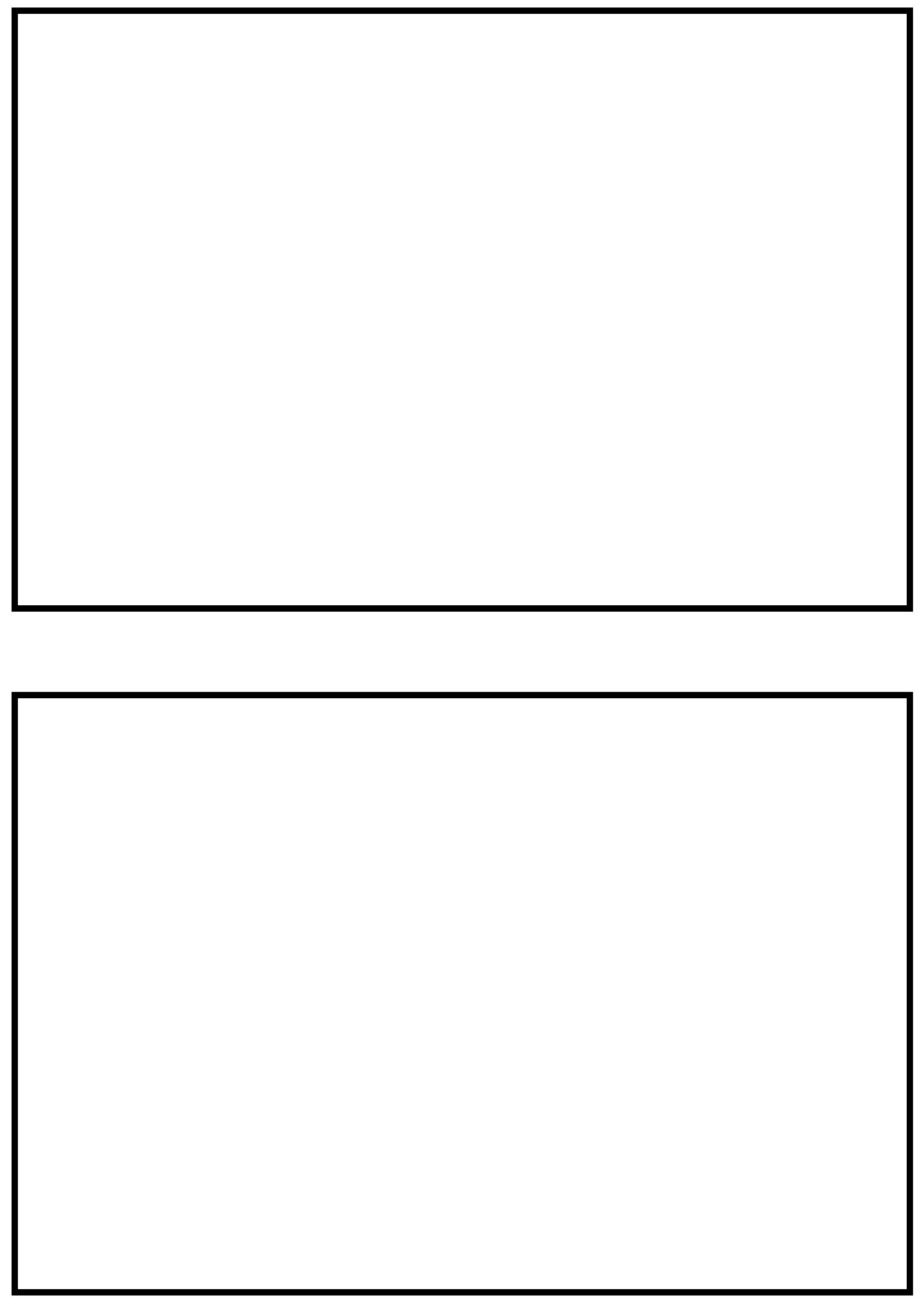

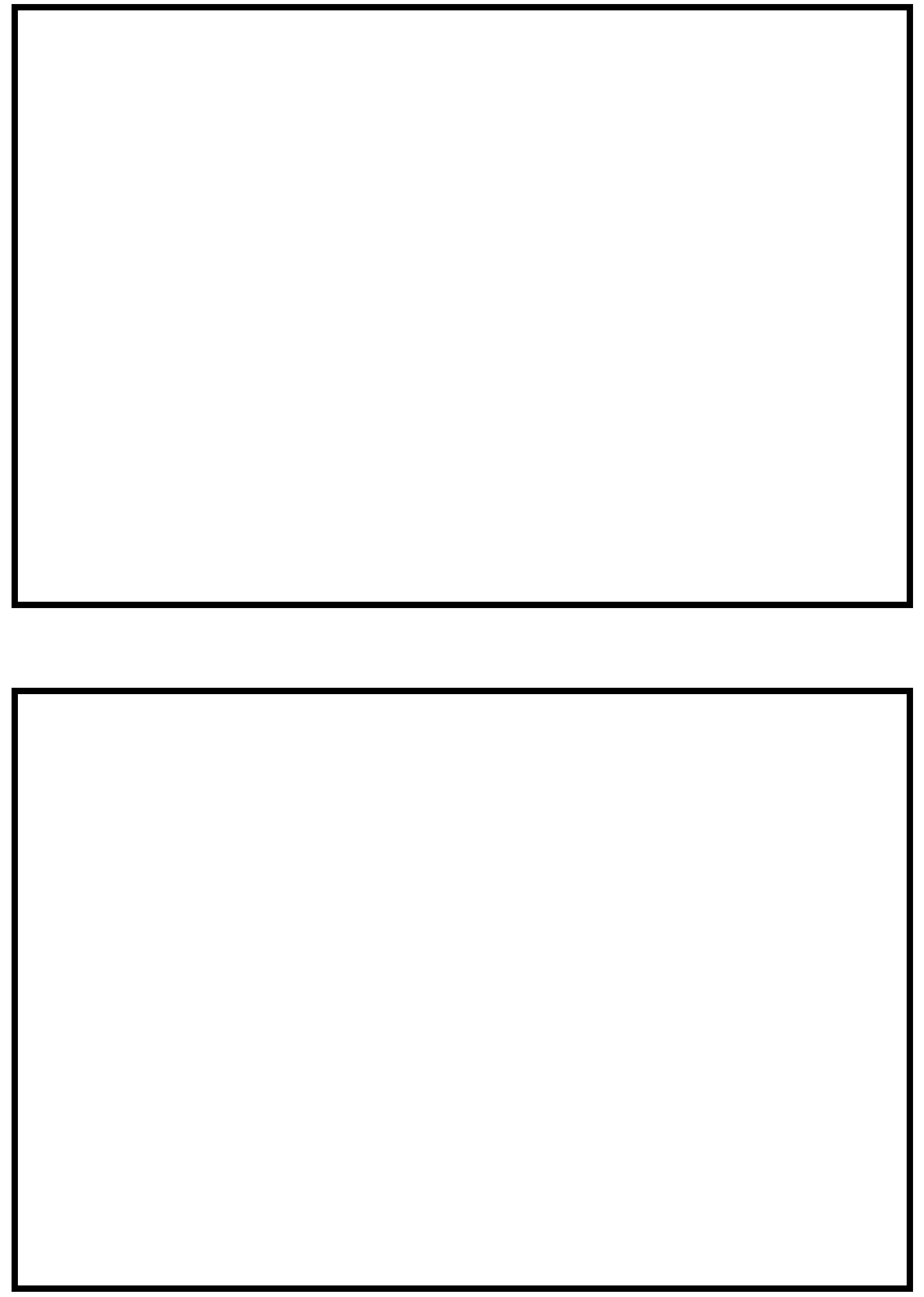


\section{LEVEL II SUMMARY}

\begin{tabular}{llllll} 
Structure Number & JAMAVT01000080 & Stream & \multicolumn{2}{c}{ West River } & \\
& & & & \\
County & Windham & Road & VT 100 & District & 2
\end{tabular}

\section{Description of Bridge}

Bridge length $\frac{246}{f t} \quad$ Bridge width $\frac{21.8}{f t} \quad$ Max span length $\frac{161}{f t}$

Alignment of bridge to road (on curve or straight)

Abutment type

Spill-through, stone

Stone fill on abutment?

$$
\text { Yes }
$$

Embankment type

Sloping

Straight

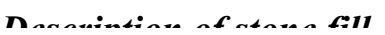

Dato af insnortion

$08 / 13 / 96$

forming a "spill-through" slope at each abutment.

Vertical abutments and piers are concrete. There is a stone "spill-through" slope at each abutment. Under the main bridge span a $3 \mathrm{ft}$ deep scour hole was observed along the left pier and a $5 \mathrm{ft}$ deep scour hole along the right pier

Is bridge skewed to flood flow according to $\mathrm{No}^{\text {No survey? }}$

Debris accumulation on bridge at time of Level I or Level II site visit:

\begin{tabular}{|c|c|c|c|}
\hline & $\begin{array}{c}\text { Date of insmortion } \\
08 / 13 / 96 \\
\end{array}$ & $\begin{array}{l}\text { Percent of alommal } \\
\text { blocked nortzontatly }\end{array}$ & $\begin{array}{l}\text { Percent of } 0 \\
\text { blocked verticatty }\end{array}$ \\
\hline & 08/13/96 & 0 & 0 \\
\hline
\end{tabular}

Level II

Moderate. There is some debris caught on the upstream side bar and

blocking flow between the right pier and right spill-through abutment.

Potential for debris

A large side bar along the right bank upstream extends through the bridge. Flow proceeds Doscriho any, fonturos noar ar at tho hridoo that mov, affort flou, (includo ahsorvation dato) around the right side of the bar impacting the right pier $08 / 13 / 96$. 


\section{Description of the Geomorphic Setting}

General topography The channel is located within a moderate relief valley with a narrow flood plain and steep valley walls on both sides.

Geomorphic conditions at bridge site: downstream (DS), upstream (US)

Date of inspection $\quad 08 / 13 / 96$

DS left: $\quad$ Moderately sloping channel bank to a narrow flood plain.

DS right: $\quad$ Moderately sloping channel bank to a narrow flood plain.

US left: $\quad$ Moderately sloping channel bank to a narrow flood plain.

US right: $\quad$ Moderately sloping channel bank to the valley wall.

\section{Description of the Channel}

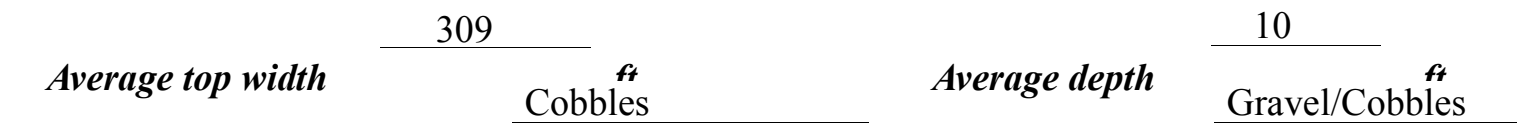

Predominant bed material

Bank material

Straight with semi-

alluvial channel boundaries and a narrow flood plain.

$08 / 13 / 96$

Vegetative co 1 Trees and brush with pasture on the flood plain.

DS left: $\quad$ Trees and brush with pasture on the flood plain.

DS right: $\quad$ Trees and brush with pasture on the flood plain.

US left: $\quad$ Trees and brush.

US right: $\quad$ Yes

Do banks appear stable? -

date of observatton.

The assessment of $08 /$

13/96 noted flow conditions are influenced by a side bar along the right bank side of the channel Describe any obstructions in channel and date of observation.

upstream. In addition, some debris is caught between the right pier and right spill-through

abutment. 


\section{Hydrology}

Drainage area $\stackrel{227}{2} \boldsymbol{m i}^{2}$

Percentage of drainage area in physiographic provinces: (approximate)

Physiographic province/section

New England/ Green Mountain
Percent of drainage area 100

Is drainage area considered rural or urban? — Rural _ Describe any significant urbanization:

Yes

Is there a USGS gage on the stream of interest?

West River at Jamaica, VT

\section{USGS gage description}

USGS gage number

Gage drainage area
01155500 179

$$
m i^{2}
$$

Yes

Is there a lake/p Townshend Lake 3.8 miles downstream in Townshënd, VT will cause backwater at the bridge. Ball Mountain Dam is upstream. Townshend Lake capacity is 1,460 million $\mathrm{ft}^{3}$. Ball Mountain Lake capacity is 2,380 million $\mathrm{ft}^{3}$ with a 172 square mile drainage area (U.S. Geological Survey Water-Data Report NH-VT-95-1).

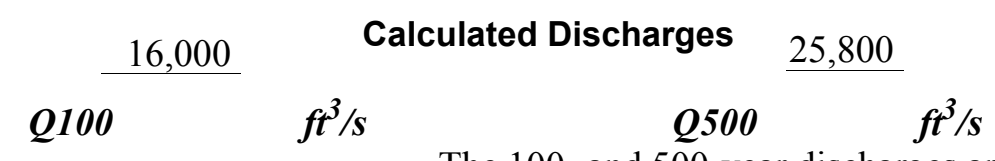

The 100- and 500-year discharges are based on the

Flood Insurance Study for the West Riyer in Jamaica, VT (Federal Emergency Management Agency, May 17, 1988). The 100-year discharge matched the same value from the VTAOT plans, see the historical form. The discharge values fell within a range of empirical methods (Benson, 1962; Johnson and Tasker, 1974; FHWA, 1983; Potter, 1957a\&b; Talbot, 1887). 


\section{Description of the Water-Surface Profile Model (WSPRO) Analysis}

Datum for WSPRO analysis (USGS survey, sea level, VTAOT plans)

USGS survey

Datum tie between USGS survey and VTAOT plans

Subtract 390.9 from the USGS

arbitrary survey datum to obtain VTAOT plans' datum.

Description of reference marks used to determine USGS datum. $\quad$ RM1 is a nail $2.5 \mathrm{ft}$. high on a

telephone pole at the right end of the downstream guard rail (elev. $502.80 \mathrm{ft}$, arbitrary survey datum).

$\underline{\mathrm{RM} 2}$ is a chiseled $\mathrm{X}$ on top of the upstream end of the left abutment bridge seat (elev. $497.53 \mathrm{ft}$,

arbitrary survey datum). RM3 is a State of Vermont tablet set in a boulder on the upstream right bank

near a garage off of River Rd. (elev. $507.69 \mathrm{ft}$, arbitrary survey datum).

survey datum).

Cross-Sections Used in WSPRO Analvsis

\begin{tabular}{|c|c|c|c|}
\hline${ }^{1}$ Cross-section & $\begin{array}{c}\text { Section } \\
\text { Reference } \\
\text { Distance } \\
\text { (SRD) in feet }\end{array}$ & $\begin{array}{c}{ }^{2} \text { Cross-section } \\
\text { development }\end{array}$ & Comments \\
\hline EXITX & -250 & 1 & Exit section \\
\hline FULLV & 0 & 2 & $\begin{array}{l}\text { Downstream Full-valley } \\
\text { section (Templated from } \\
\text { EXITX) }\end{array}$ \\
\hline BRIDG & 0 & 1 & Bridge section \\
\hline RDWAY & 13 & 1 & Road Grade section \\
\hline APPRO & 263 & 2 & $\begin{array}{l}\text { Modelled Approach sec- } \\
\text { tion (Templated from } \\
\text { APTEM) }\end{array}$ \\
\hline APTEM & 286 & 1 & $\begin{array}{l}\text { Approach section as sur- } \\
\text { veyed (Used as a tem- } \\
\text { plate) }\end{array}$ \\
\hline
\end{tabular}




\section{Data and Assumptions Used in WSPRO Model}

Hydraulic analyses of the reach were done by use of the Federal Highway Administration's WSPRO step-backwater computer program (Shearman and others, 1986, and Shearman, 1990). The analyses reported herein reflect conditions existing at the site at the time of the study. Furthermore, in the development of the model it was necessary to assume no accumulation of debris or ice at the site. Results of the hydraulic model are presented in the Bridge Hydraulic Summary, Appendix B, and figure 7.

Channel roughness factors (Manning's " $n$ ") used in the hydraulic model were estimated using field inspections at each cross section following the general guidelines described by Arcement and Schneider (1989). Final adjustments to the values were made during the modelling of the reach. Channel " $n$ " values for the reach ranged from 0.035 to 0.045 , and overbank " $\mathrm{n}$ " values ranged from 0.035 to 0.085 .

Normal depth at the exit section (EXITX) was assumed as the starting water surface. This depth was computed by use of the slope-conveyance method outlined in the user's manual for WSPRO (Shearman, 1990). The slope used was $0.0068 \mathrm{ft} / \mathrm{ft}$ which

was estimated from the 100-year discharge water surface slope downstream of the bridge in the Flood Insurance Study for Jamaica, VT (Federal Emergency Management Agency, May 17, 1988). Downstream, Townshend Lake Dam forms backwater to the bridge up to the elevation of the spillway at 553.0 feet NGVD (493 feet USGS arbitrary survey datum). The backwater effects were not included in the analysis. During a flood event normal depth at the bridge would be the lowest potential depth.

The surveyed approach section (APTEM) was moved along the approach channel slope $(0.0070 \mathrm{ft} / \mathrm{ft})$ to establish the modelled approach section (APPRO), one bridge length upstream of the upstream face as recommended by Shearman and others (1986). This approach also provides a consistent method for determining scour variables.

A two foot diameter concrete culvert was located along the base of the left road approach embankment draining water from the upstream left flood plain. The culvert was not included in the hydraulic analysis because it was assumed to have negligible effect at the modeled discharges. 


\section{Bridge Hydraulics Summary}

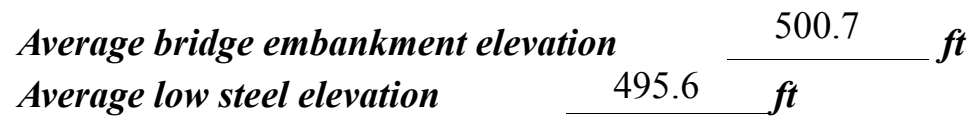

$$
\text { 100-year discharge } \quad 16,000 \quad \mathrm{ft}^{3} / \mathrm{s}
$$

Water-surface elevation in bridge opening $\quad 489.1 \quad f$

Road overtopping? ___ No Discharge over road ___

Area of flow in bridge opening $\quad 1,974 \quad \mathrm{ft}^{2}$

Average velocity in bridge opening $\quad 8.1 \quad \mathrm{ft} / \mathrm{s}$

$\begin{array}{llll}\text { Maximum WSPRO tube velocity at bridge } & 9.6 \mathrm{ft} / \mathrm{s}\end{array}$

Water-surface elevation at Approach section with bridge 490.6

Water-surface elevation at Approach section without bridge $\quad \begin{array}{r}490.2 \\ \hline\end{array}$

Amount of backwater caused by bridge $\quad 0.4$ it

500-year discharge $\quad 25,800 \quad \mathrm{ft}^{3} / \mathrm{s}$

Water-surface elevation in bridge opening $\quad 490.7 \mathrm{ft}$

Road overtopping? ___ No Discharge over road ___ --,

Area of flow in bridge opening $\quad 2,320 \quad \mathrm{ft}^{2}$

Average velocity in bridge opening $11.1 \mathrm{ft} / \mathrm{s}$

Maximum WSPRO tube velocity at bridge 13.0 /s

Water-surface elevation at Approach section with bridge 492.9

Water-surface elevation at Approach section without bridge $\quad 492.2$

Amount of backwater caused by bridge 0.7 .

Incipient overtopping discharge ___ -- $\mathrm{ft}^{3} / \mathrm{s}$

Water-surface elevation in bridge opening $\quad--\quad t$

Area of flow in bridge opening _ $\quad--\quad \mathrm{ft}^{2}$

Average velocity in bridge opening ___ $\quad--\quad \mathrm{ft} / \mathrm{s}$

Maximum WSPRO tube velocity at bridge $\quad--\quad f t / s$

Water-surface elevation at Approach section with bridge

Water-surface elevation at Approach section without bridge

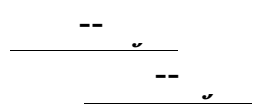

Amount of backwater caused by bridge __ - ${ }_{-}$it 


\section{Scour Analysis Summary}

\section{Special Conditions or Assumptions Made in Scour Analysis}

Scour depths were computed using the general guidelines described in Hydraulic Engineering Circular 18 (Richardson and others, 1995). Scour depths were calculated assuming an infinite depth of erosive material and a homogeneous particle-size distribution. The results of the scour analysis are presented in tables 1 and 2 and a graph of the scour depths is presented in figure 8 .

Contraction scour for the 100-year discharge was computed by use of the clear-water contraction scour equation (Richardson and others, 1995, p. 32, equation 20). Contraction scour for the 500-year discharge was computed by use of Laursen's live bed contraction scour equation (Richardson and others, 1995, p. 30, equations 17 and 18).

Abutment scour was computed by use of the Froehlich equation (Richardson and others, 1995, p. 48, equation 28). Variables for the Froehlich equation include the Froude number of the flow approaching the embankments, the length of the embankment blocking flow, and the depth of flow approaching the embankment less any roadway overtopping.

Pier scour was computed by use of the Colorado State University pier scour equation (Richardson and others, 1995, p. 36, equation 21). Variables for the Colorado State University pier scour equation include the Froude number of the flow approaching the pier, pier width to the depth of flow ratio, and correction factors for the pier nose shape, angle of attack of flow, bed condition, and armoring by bed material size.

Because the influence of scour processes on the spill-through embankment material is uncertain, the scour depth at the vertical concrete abutment walls is unknown. Therefore, the total scour depths were applied for the entire spill-through embankment below the elevation at the toe of each embankment, as shown in figure 8 . The right embankment scour depth was greater than the right pier scour depth and was extended under the pier. 


\section{Scour Results}

100-yr discharge 500-yr discharge

Contraction scour:

(Scour depths in feet)

Main channel

Live-bed scour

Clear-water scour

Depth to armoring

Left overbank

Right overbank

Local scour:

Abutment scour

Left abutment

15.8

18.6

19.4

23.9-

Right abutment

Pier scour

Pier 1

9.5

14.4

15.0

Pier 2

Pier 3

Abutments:

Left abutment

Right abutment

Piers:

Pier 1

Pier 2

\section{Riprap Sizing}

Incipient overtopping 100-yrdischarge 500-yrdischarge discharge

1.9

1.9

$1.0^{-}$

1.0

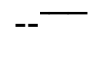

overtopping discharge
Incipient 


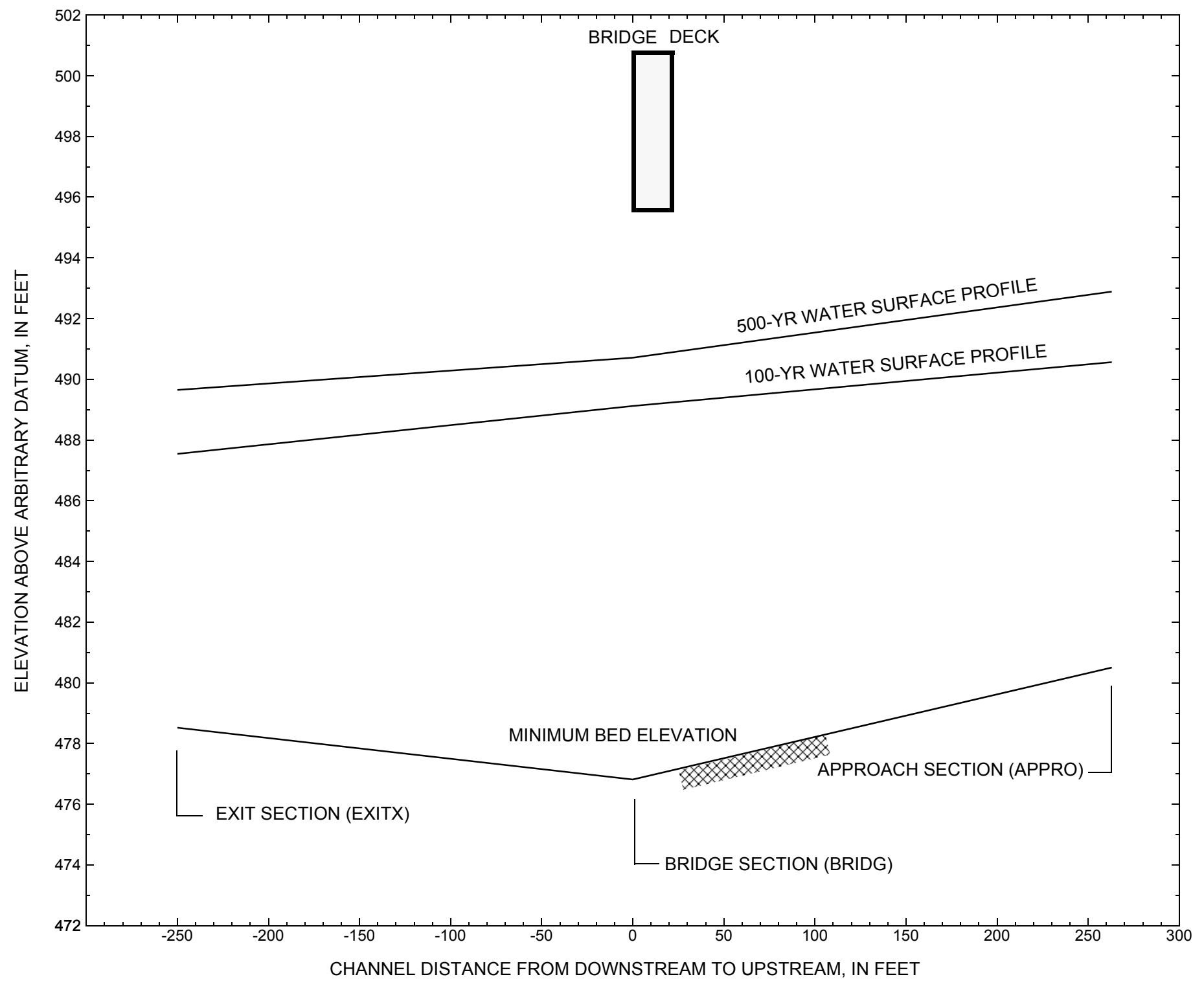

Figure 7. Water-surface profiles for the 100- and 500-yr discharges at structure JAMAVT01000080 on State Route 100, crossing the West River, Jamaica, Vermont. 


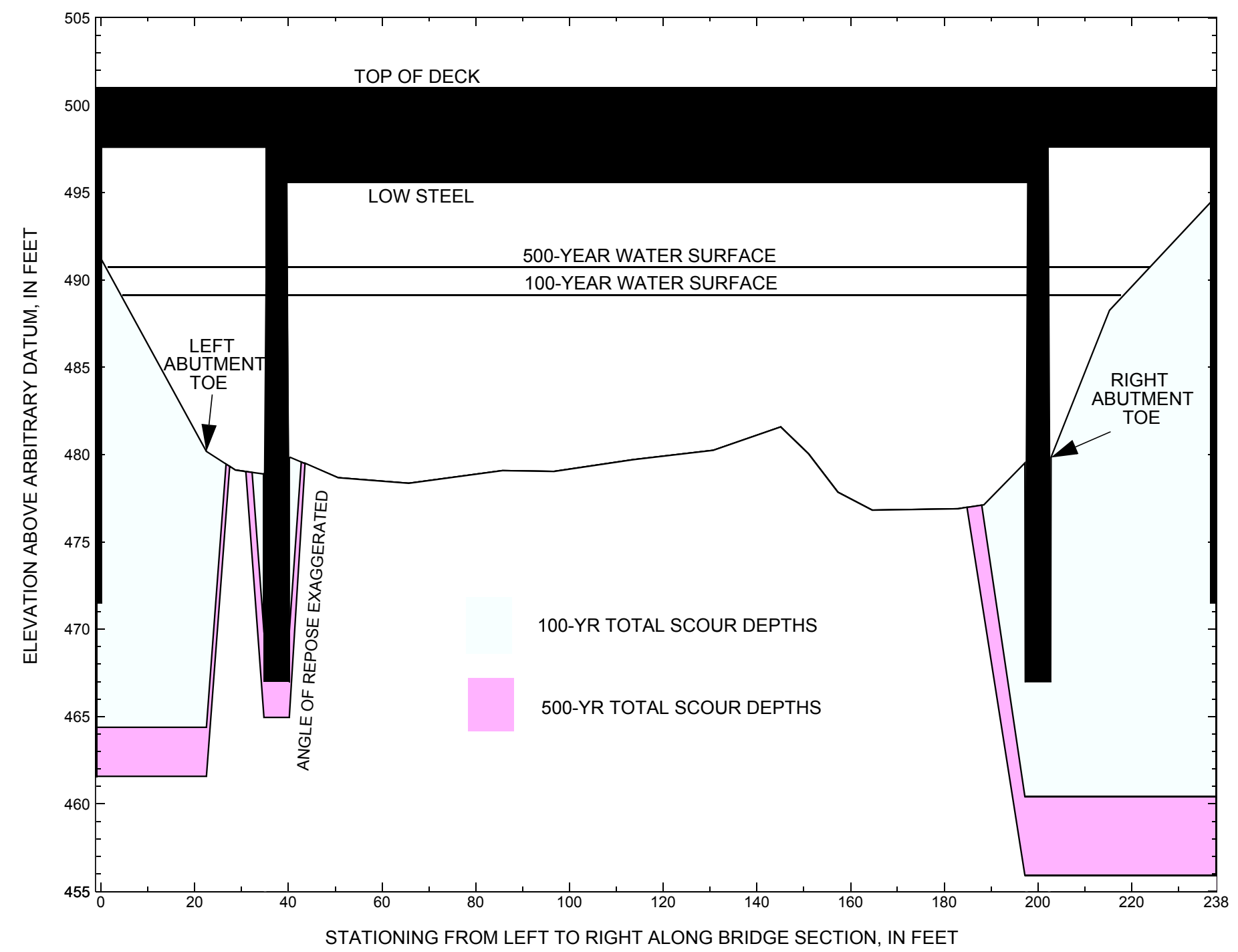

Figure 8. Scour elevations for the 100-yr and 500-yr discharges at structure JAMAVT01000080 on State Route 100, crossing the West River, Jamaica, Vermont. 
Table 1. Remaining footing/pile depth at abutments for the 100-year discharge at structure JAMAVT01000080 on State Route 100, crossing the West River, Jamaica, Vermont. [VTAOT, Vermont Agency of Transportation; --,no data]

\begin{tabular}{|c|c|c|c|c|c|c|c|c|c|c|c|}
\hline Description & Station $^{1}$ & $\begin{array}{l}\text { VTAOT } \\
\text { bridge seat } \\
\text { elevation } \\
\text { (feet) }\end{array}$ & $\begin{array}{l}\text { Surveyed } \\
\text { minimum } \\
\text { low-chord } \\
\text { elevation }{ }^{2} \\
\text { (feet) }\end{array}$ & $\begin{array}{c}\text { Bottom of } \\
\text { footing } \\
\text { elevation } \\
\text { (feet) }\end{array}$ & $\begin{array}{c}\text { Channel } \\
\text { elevation at } \\
\text { abutment/ } \\
\text { pier }^{2} \\
\text { (feet) }\end{array}$ & $\begin{array}{l}\text { Contraction } \\
\text { scour depth } \\
\text { (feet) }\end{array}$ & $\begin{array}{l}\text { Abutment } \\
\text { scour } \\
\text { depth } \\
\text { (feet) }\end{array}$ & $\begin{array}{l}\text { Pier } \\
\text { scour } \\
\text { depth } \\
\text { (feet) }\end{array}$ & $\begin{array}{l}\text { Depth of } \\
\text { total scour } \\
\text { (feet) }\end{array}$ & $\begin{array}{c}\text { Elevation of } \\
\text { scour }^{2} \\
\text { (feet) }\end{array}$ & $\begin{array}{c}\text { Remaining } \\
\text { footing/pile } \\
\text { depth } \\
\text { (feet) }\end{array}$ \\
\hline \multicolumn{12}{|c|}{100 -yr. discharge is 16,000 cubic-feet per second } \\
\hline Left abutment & 0.0 & 106.6 & 497.6 & 471.5 & 491.2 & 0.0 & -- & -- & -- & -- & -7.1 \\
\hline $\begin{array}{l}\text { Toe of spill- } \\
\text { through slope }\end{array}$ & 22.5 & -- & -- & -- & 480.2 & 0.0 & 15.8 & -- & 15.8 & 464.4 & -- \\
\hline Left Pier & 37.5 & -- & 495.6 & 467.0 & 479.4 & 0.0 & -- & 9.5 & 9.5 & 469.9 & 2.9 \\
\hline Right Pier & 200.0 & -- & 495.6 & 467.0 & 480.0 & 0.0 & -- & 15.0 & 15.0 & 465.0 & -2.0 \\
\hline $\begin{array}{l}\text { Toe of spill- } \\
\text { through slope }\end{array}$ & 202.5 & -- & -- & -- & 479.8 & 0.0 & 19.4 & -- & 19.4 & 460.4 & -- \\
\hline Right abutment & 237.1 & 106.6 & 497.6 & 471.5 & 494.5 & 0.0 & -- & -- & -- & -- & -11.1 \\
\hline
\end{tabular}

1.Measured along the face of the most constricting side of the bridge.

2.Arbitrary datum for this study.

Table 2. Remaining footing/pile depth at abutments for the 500-year discharge at structure JAMAVT01000080 on State Route 100, crossing the West River, Jamaica, Vermont. [VTAOT, Vermont Agency of Transportation; --, no data]

\begin{tabular}{|c|c|c|c|c|c|c|c|c|c|c|c|}
\hline Description & Station $^{1}$ & $\begin{array}{l}\text { VTAOT } \\
\text { bridge seat } \\
\text { elevation } \\
\text { (feet) }\end{array}$ & $\begin{array}{l}\text { Surveyed } \\
\text { minimum } \\
\text { low-chord } \\
\text { elevation } \\
\text { (feet) }\end{array}$ & $\begin{array}{l}\text { Bottom of } \\
\text { footing } \\
\text { elevation } \\
\text { (feet) }\end{array}$ & $\begin{array}{c}\text { Channel } \\
\text { elevation at } \\
\text { abutment/ } \\
\text { pier }^{2} \\
\text { (feet) }\end{array}$ & $\begin{array}{l}\text { Contraction } \\
\text { scour depth } \\
\text { (feet) }\end{array}$ & $\begin{array}{l}\text { Abutment } \\
\text { scour } \\
\text { depth } \\
\text { (feet) }\end{array}$ & $\begin{array}{l}\text { Pier } \\
\text { scour } \\
\text { depth } \\
\text { (feet) }\end{array}$ & $\begin{array}{l}\text { Depth of } \\
\text { total scour } \\
\text { (feet) }\end{array}$ & $\begin{array}{c}\text { Elevation of } \\
\text { scour }^{2} \\
\text { (feet) }\end{array}$ & $\begin{array}{c}\text { Remaining } \\
\text { footing/pile } \\
\text { depth } \\
\text { (feet) }\end{array}$ \\
\hline \multicolumn{12}{|c|}{500 -yr. discharge is 25,800 cubic-feet per second } \\
\hline Left abutment & 0.0 & 106.6 & 497.6 & 471.5 & 491.2 & 0.0 & -- & -- & -- & -- & -9.9 \\
\hline $\begin{array}{l}\text { Toe of spill- } \\
\text { through slope }\end{array}$ & 22.5 & -- & -- & -- & 480.2 & 0.0 & 18.6 & -- & 18.6 & 461.6 & -- \\
\hline Left Pier & 37.5 & -- & 495.6 & 467.0 & 479.4 & 0.0 & -- & 14.4 & 14.4 & 465.0 & -2.0 \\
\hline Right Pier & 200.0 & -- & 495.6 & 467.0 & 480.0 & 0.0 & -- & 22.8 & 22.8 & 457.2 & -9.8 \\
\hline $\begin{array}{l}\text { Toe of spill- } \\
\text { through slope }\end{array}$ & 202.5 & -- & -- & -- & 479.8 & 0.0 & 23.9 & -- & 23.9 & 455.9 & -- \\
\hline Right abutment & 237.1 & 106.6 & 497.6 & 471.5 & 494.5 & 0.0 & -- & -- & -- & -- & -15.6 \\
\hline
\end{tabular}

1.Measured along the face of the most constricting side of the bridge.

2.Arbitrary datum for this study. 


\section{SELECTED REFERENCES}

Arcement, G.J., Jr., and Schneider, V.R., 1989, Guide for selecting Manning's roughness coefficients for natural channels and flood plains: U.S. Geological Survey Water-Supply Paper 2339, 38 p.

Barnes, H.H., Jr., 1967, Roughness characteristics of natural channels: U.S. Geological Survey Water-Supply Paper 1849,213 p.

Benson, M. A., 1962, Factors Influencing the Occurrence of Floods in a Humid Region of Diverse Terrain: U.S. Geological Survey WaterSupply Paper 1580-B, 64 p.

Brown, S.A. and Clyde, E.S., 1989, Design of riprap revetment: Federal Highway Administration Hydraulic Engineering Circular No. 11, Publication FHWA-IP-89-016, 156 p.

Federal Highway Administration, 1983, Runoff estimates for small watersheds and development of sound design: Federal Highway Administration Report FHWA-RD-77-158

Federal Emergency Management Agency, 1988, Flood Insurance Study, Town of Jamaica, Windham County, Vermont: Washington, D.C., May 17, 1988.

Froehlich, D.C., 1989, Local scour at bridge abutments in Ports, M.A., ed., Hydraulic Engineering--Proceedings of the 1989 National Conference on Hydraulic Engineering: New York, American Society of Civil Engineers, p. 13-18.

Hayes, D.C.,1993, Site selection and collection of bridge-scour data in Delaware, Maryland, and Virginia: U.S. Geological Survey WaterResources Investigation Report 93-4017, 23 p.

Interagency Advisory Committee on Water Data, 1982, Guidelines for determining flood flow frequency: U.S. Geological Survey, Bulletin 17B of the Hydrology Subcommittee, 190 p.

Johnson, C.G. and Tasker, G.D.,1974, Progress report on flood magnitude and frequency of Vermont streams: U.S. Geological Survey OpenFile Report 74-130, 37 p.

Lagasse, P.F., Schall, J.D., Johnson, F., Richardson, E.V., Chang, F., 1995, Stream Stability at Highway Structures: Federal Highway Administration Hydraulic Engineering Circular No. 20, Publication FHWA-IP-90-014, 144 p.

Laursen, E.M., 1960, Scour at bridge crossings: Journal of the Hydraulics Division, American Society of Civil Engineers, v. 86, no. HY2, p. 39-53.

Potter, W. D., 1957a, Peak rates of runoff in the Adirondack, White Mountains, and Maine woods area, Bureau of Public Roads

Potter, W. D., 1957b, Peak rates of runoff in the New England Hill and Lowland area, Bureau of Public Roads

Richardson, E.V. and Davis, S.R., 1995, Evaluating scour at bridges: Federal Highway Administration Hydraulic Engineering Circular No. 18, Publication FHWA-IP-90-017, 204 p.

Richardson, E.V., Simons, D.B., and Julien, P.Y., 1990, Highways in the river environment: Federal Highway Administration Publication FHWA-HI-90-016.

Ritter, D.F., 1984, Process Geomorphology: W.C. Brown Co., Debuque, Iowa, 603 p.

Shearman, J.O., 1990, User's manual for WSPRO--a computer model for water surface profile computations: Federal Highway Administration Publication FHWA-IP-89-027, 187 p.

Shearman, J.O., Kirby, W.H., Schneider, V.R., and Flippo, H.N., 1986, Bridge waterways analysis model; research report: Federal Highway Administration Publication FHWA-RD-86-108, 112 p.

Talbot, A.N., 1887, The determination of water-way for bridges and culverts.

U.S. Department of Transportation, 1993, Stream stability and scour at highway bridges, Participant Workbook: Federal Highway Administration Publication FHWA HI-91-011.

U.S. Geological Survey, 1984, Townshend, Vermont 7.5 Minute Series quadrangle map: U.S. Geological Survey Topographic Maps, Scale $1: 25,000$. 


\section{APPENDIX A: \\ WSPRO INPUT FILE}




\section{WSPRO INPUT FILE}

GR

GR

GR

GR

$\mathrm{N}$

SA

*

XS

*

BR

GR

GR

GR

GR

GR

GR

GR

GR

CD

PW

$\mathrm{N}$

$\mathrm{XR}$

GR

GR

GR

GR

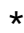

$\mathrm{XT}$

GR

GR

GR

GR

GR

GR

GR

U.S. Geological Survey WSPRO Input File jama080.wsp

Hydraulic analysis for structure JAMAVT01000080 Date: 30-JAN-97 Bridge \# 80 on VT 100 over the West River in Jamaica, VT by MAI

$\begin{array}{lllllllllllllllllllll}6 & 29 & 30 & 552 & 553 & 551 & 5 & 16 & 17 & 13 & 3 & * & 15 & 14 & 23 & 21 & 11 & 12 & 4 & 7 & 3\end{array}$

$16000 \quad 25800$

$0.0068 \quad 0.0068$

Left overbank of EXITX assumed flat. The width of the floodplain taken from FEMA model.

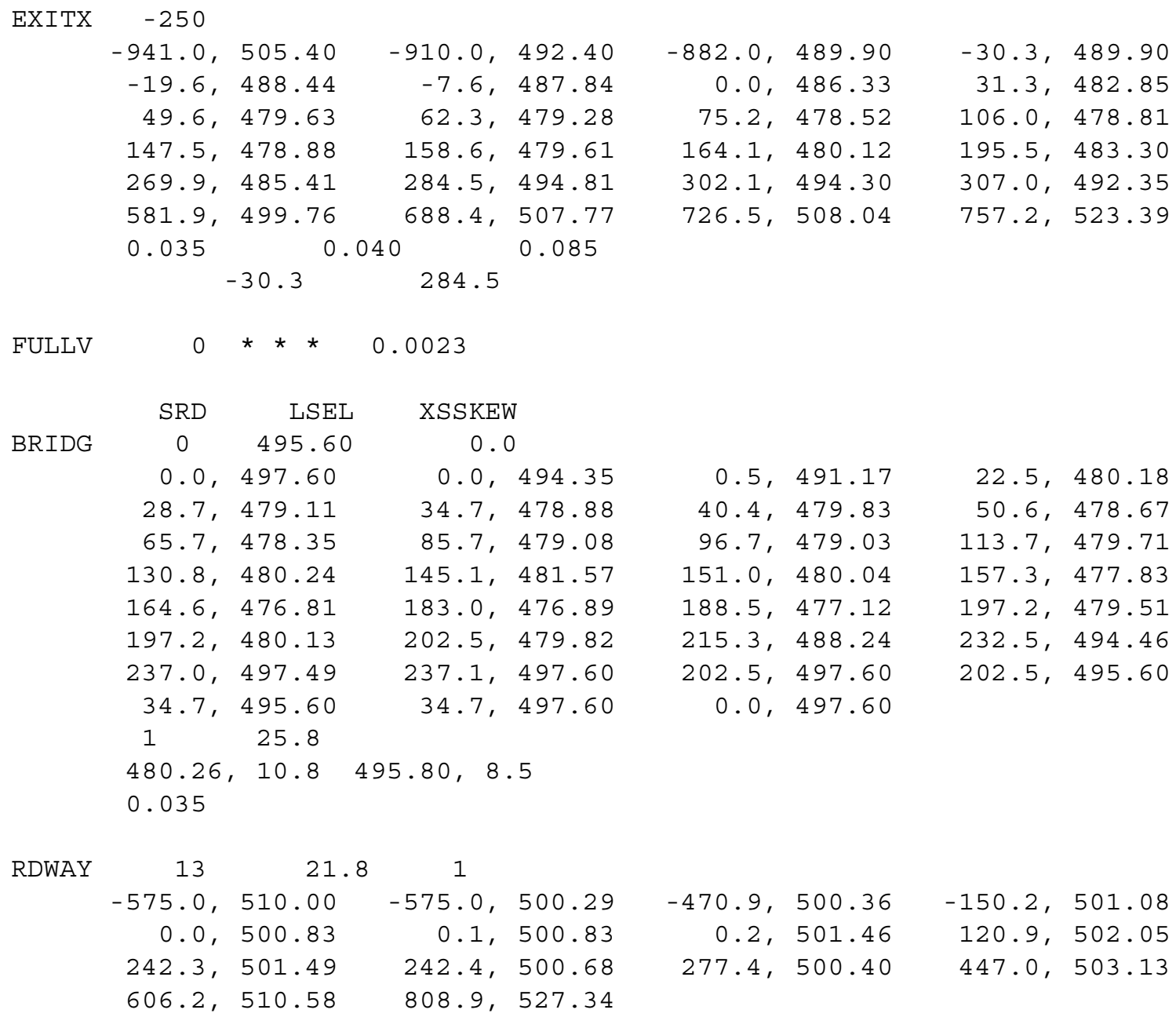

First line of GR data below was taken from FEMA flood insurance study. (From left edge to left top of bank)

APTEM 286

$$
\begin{array}{r}
-641.3,499.90 \\
-23.3,493.28 \\
19.4,481.78 \\
68.7,481.55 \\
106.2,484.30 \\
229.4,483.50 \\
321.1,498.08
\end{array}
$$

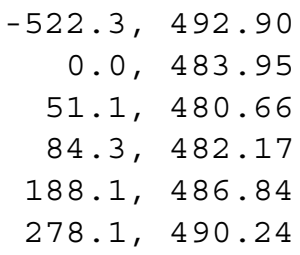

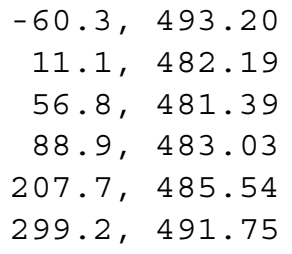


WSPRO INPUT FILE (continued)

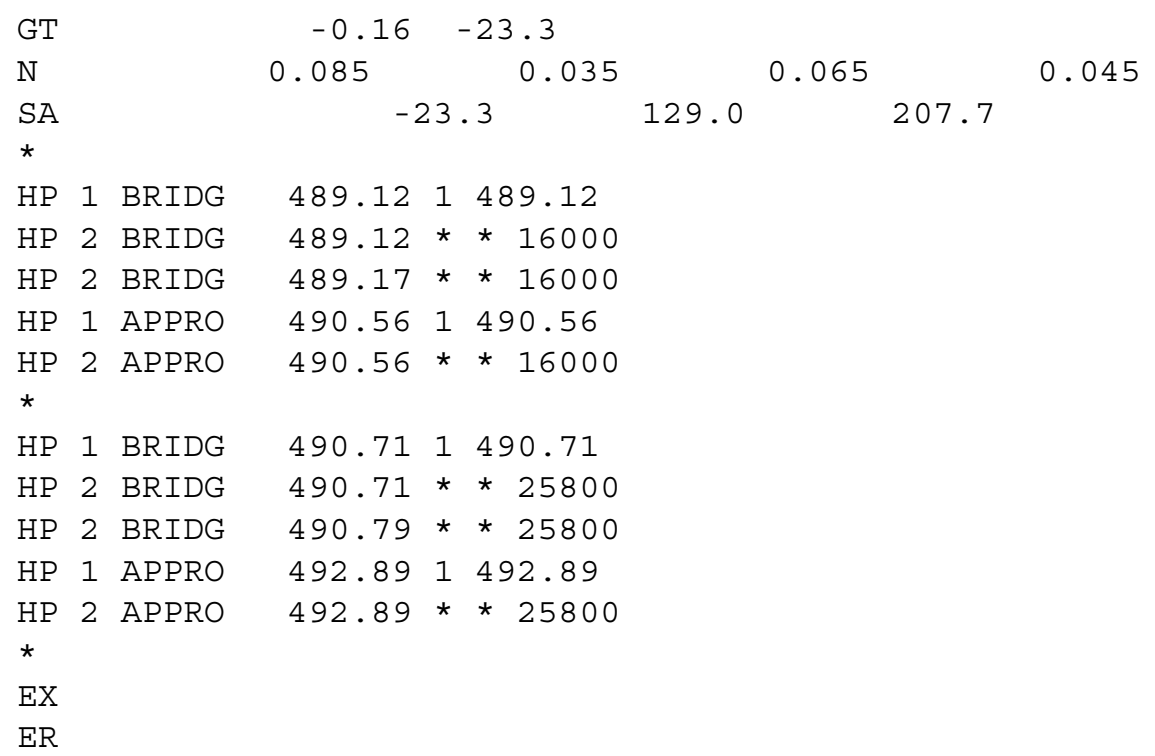




\section{APPENDIX B: \\ WSPRO OUTPUT FILE}




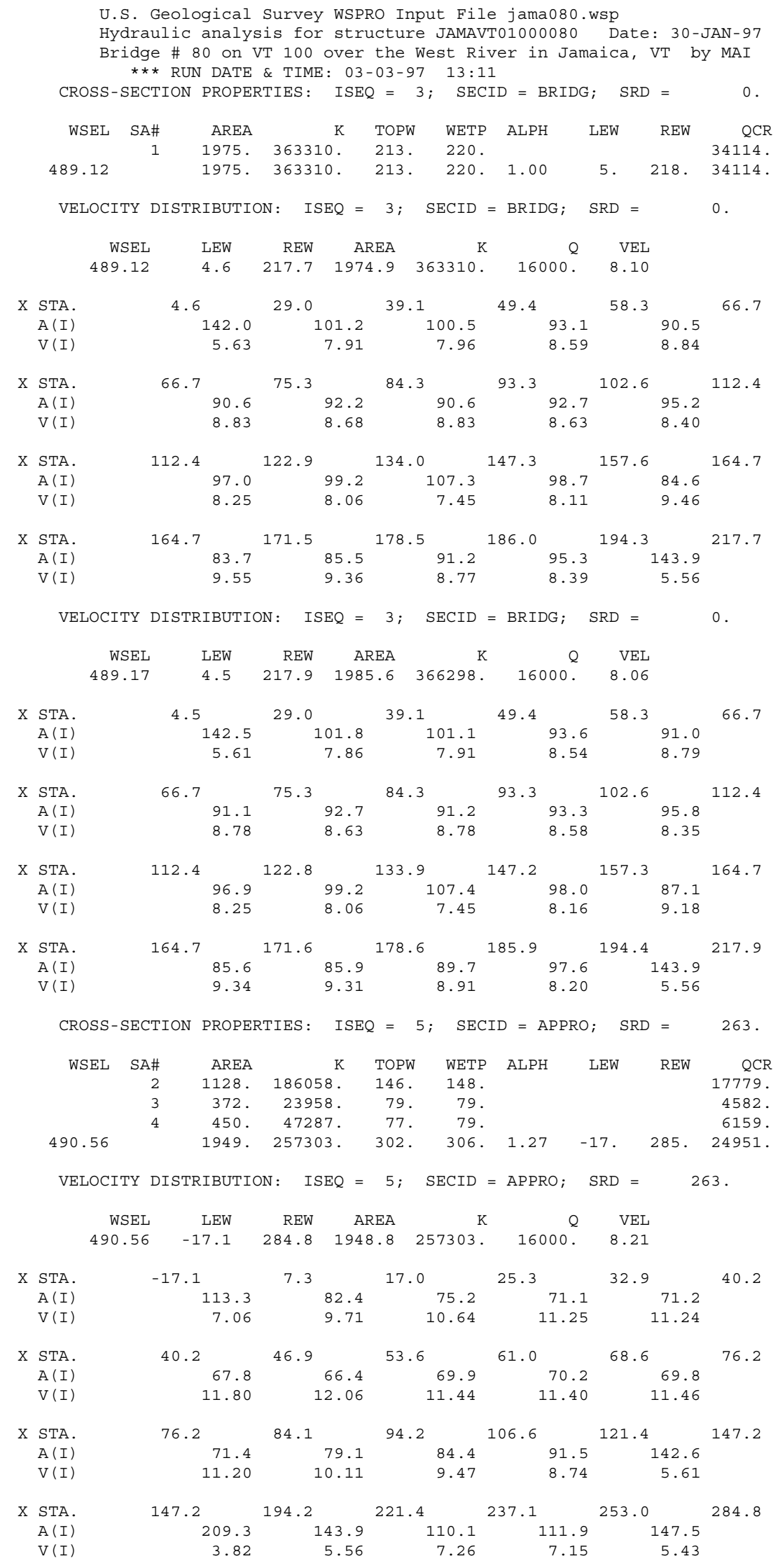




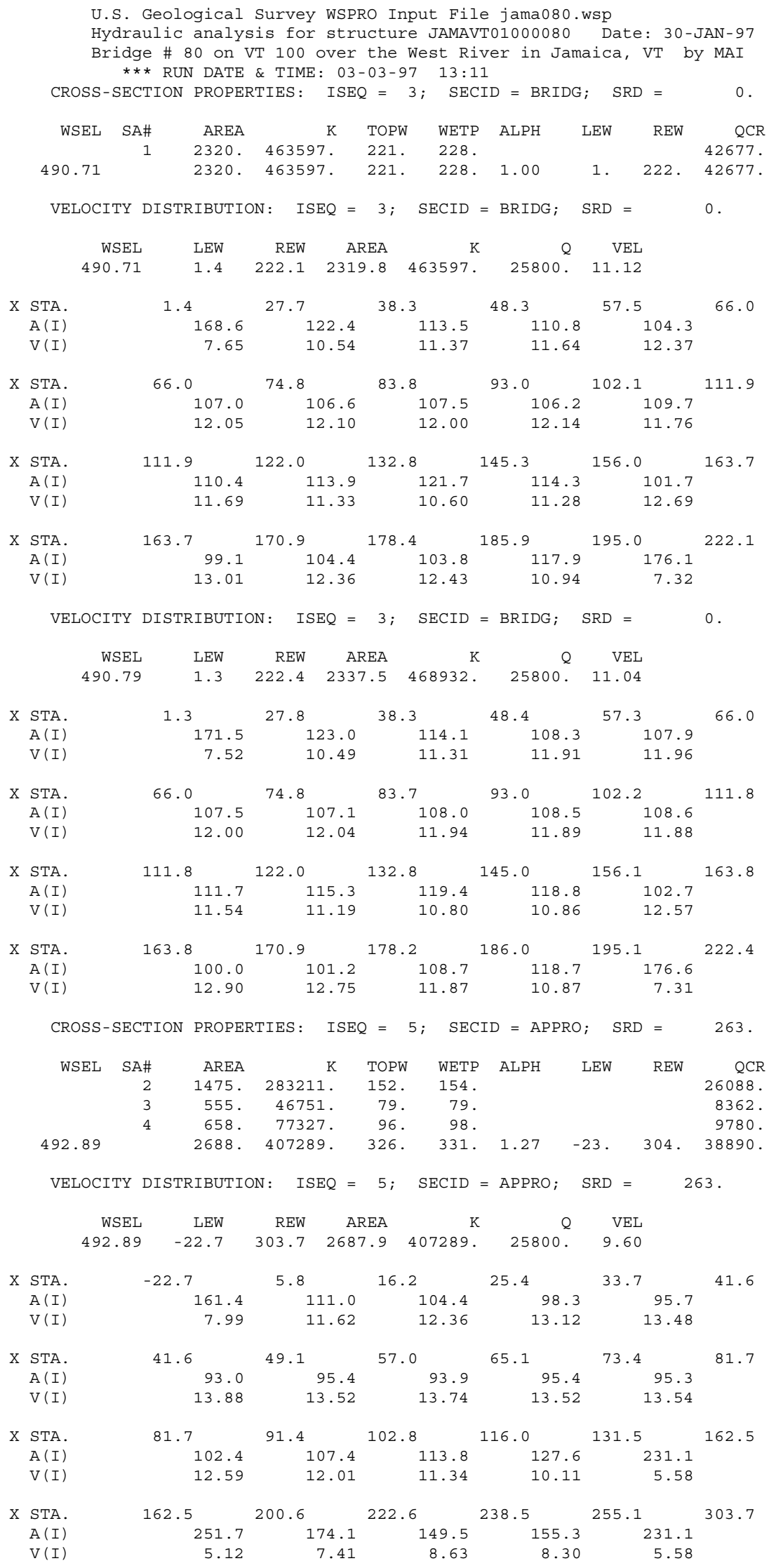


WSPRO OUTPUT FILE (continued)

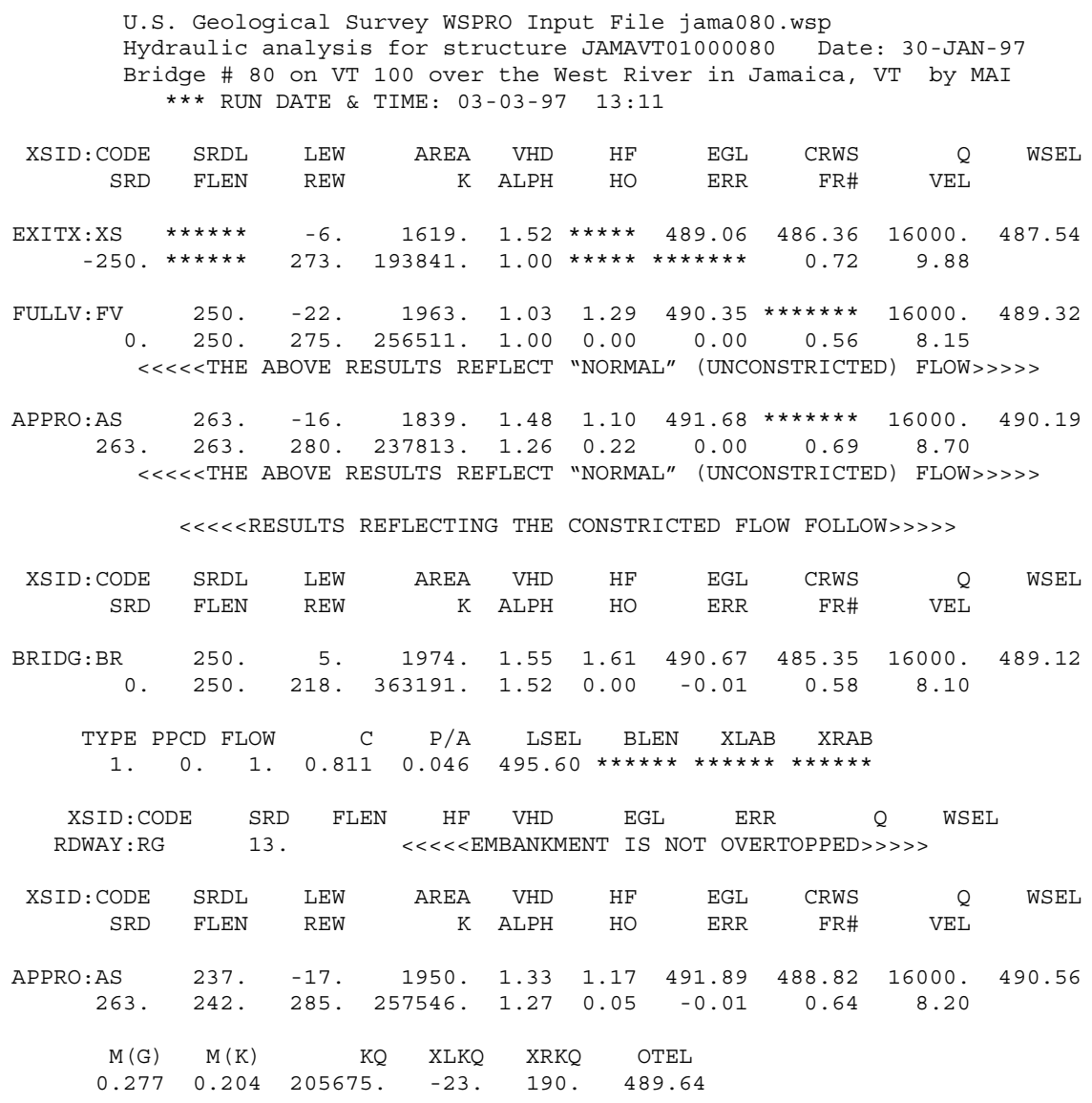

FIRST USER DEFINED TABLE.

\begin{tabular}{|c|c|c|c|c|c|c|c|c|}
\hline XSID : CODE & SRD & LEW & REW & Q & K & AREA & VEL & WSEL \\
\hline EXITX:XS & -250 & -6 & 273. & 16000. & 193841. & 1619. & 9.88 & 487.54 \\
\hline FULLV: FV & 0 . & -22 & 275. & 16000. & 256511. & 1963. & 8.15 & 489.32 \\
\hline BRIDG : BR & 0 . & 5. & 218. & 16000. & 363191. & 1974. & 8.10 & 489.12 \\
\hline RDWAY : RG & $13 . *$ & $* \star \star \star \star \star \star *$ & 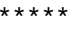 & 0 . & 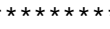 & $* \star \star \star \star \star *$ & $1.00 *$ & 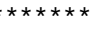 \\
\hline APPRO: AS & 263. & -17 & 285 . & 16000. & 257546 . & 1950. & 8.20 & 490.56 \\
\hline XSID : CODE & XLKQ & XRKQ & \multirow{2}{*}{\multicolumn{4}{|c|}{ KQ }} & & \\
\hline APPRO:AS & -23 & 190. & & & & & & \\
\hline
\end{tabular}

SECOND USER DEFINED TABLE.

\begin{tabular}{|c|c|c|c|c|c|c|c|c|c|}
\hline XSID : CODE & CRWS & FR\# & YMIN & YMAX & $\mathrm{HF}$ & $\mathrm{HO}$ & VHD & EGL & WSEL \\
\hline EXITX:XS & 486.36 & 0.72 & 478.52 & $523.39 *$ & 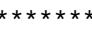 & 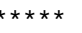 & 1.52 & 489.06 & 87.54 \\
\hline FULL & $\star \star \star \star * \star * \star * *$ & 0.56 & 479.10 & 523.97 & 1.29 & 0.00 & 1.03 & 490.35 & 489.32 \\
\hline BRIDG : BR & 485.35 & 0.58 & 476.81 & 497.60 & 1.61 & 0.00 & 1.55 & 490.67 & 489.12 \\
\hline : RG & 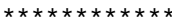 & $\star \star \star \star \star * *$ & 500.29 & $527.34 x$ & $* * * *$ & & & $5 \mathrm{nn}$ & 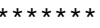 \\
\hline PPRO : AS & 488.82 & 0.64 & 480.50 & 507.27 & 1.17 & .05 & 33 & 491.89 & 490 \\
\hline
\end{tabular}


WSPRO OUTPUT FILE (continued)

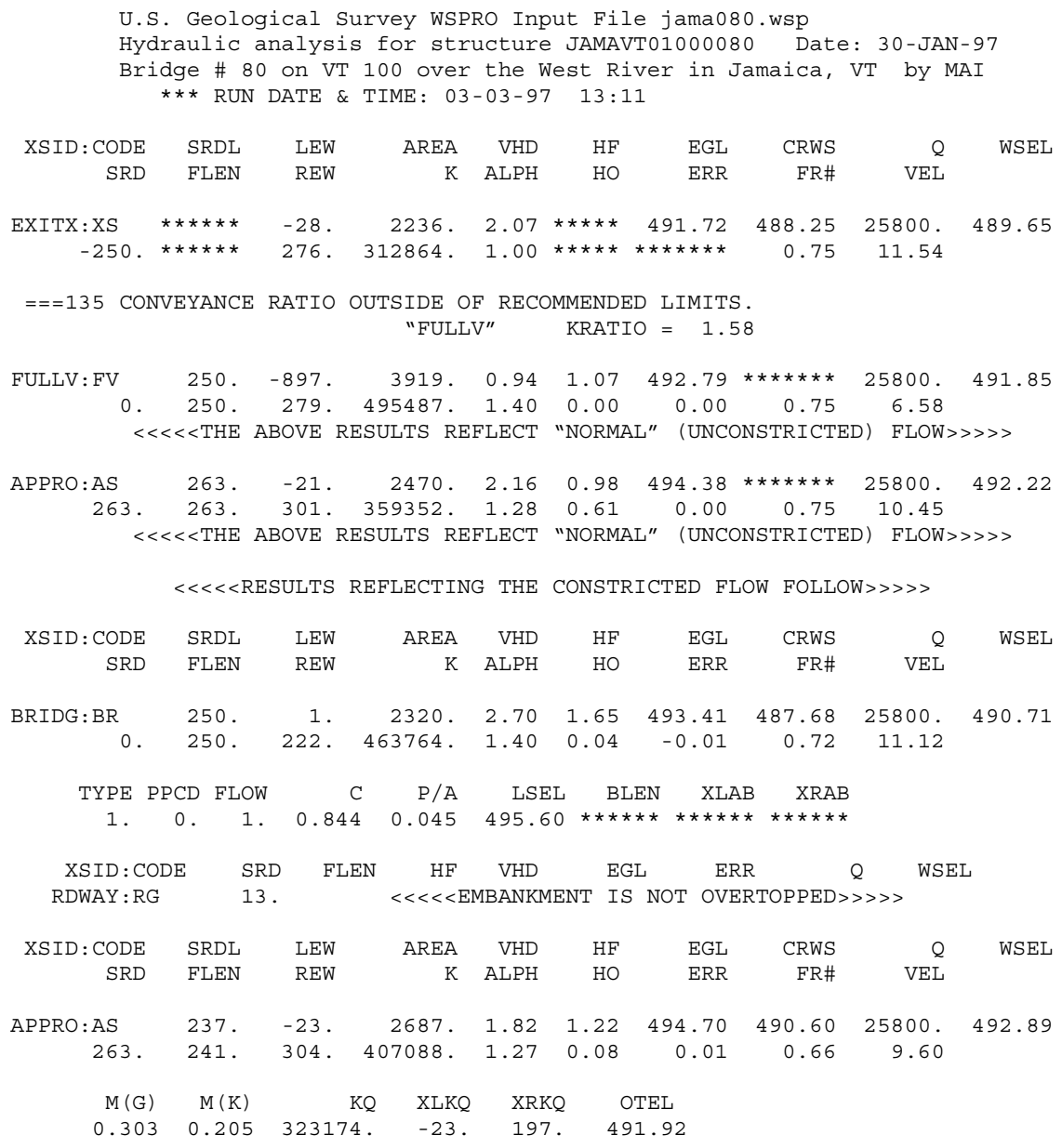




\section{APPENDIX C:}

\section{BED-MATERIAL PARTICAL-SIZE DISTRIBUTION}




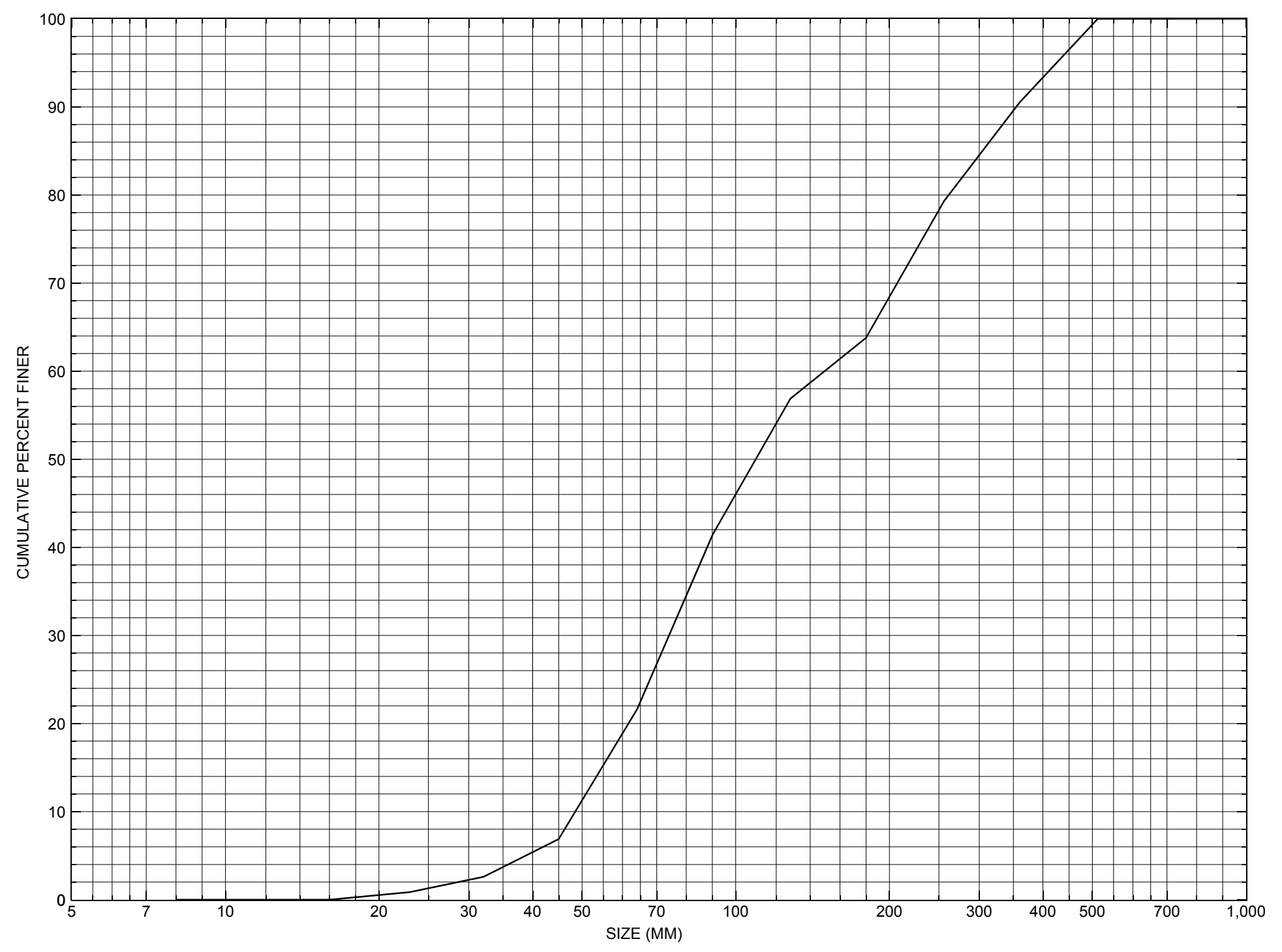

Appendix C. Bed material particle-size distribution for a pebble count in the channel approach of structure JAMAVT01000080, in Jamaica, Vermont. 


\section{APPENDIX D: \\ HISTORICAL DATA FORM}




\section{Structure Number JAMAVT01000080}

\section{General Location Descriptive}

Data collected by (First Initial, Full last name) $\mathbf{M}$. IVANOFF

Date $(M M / D D / Y Y) \_\mathbf{0 3} / \underline{\mathbf{3 0} /} \mathbf{9 5}$

Highway District Number (I - 2; nn) $\mathbf{0 2}$

Town (FIPS place code; I - 4; nnnnn) $\mathbf{3 6 1 7 5}$

Waterway (I - 6) WEST RIVER

Route Number VT100

Topographic Map Townshend

Latitude (I - 16; nnnn.n) $\mathbf{4 3 0 4 4}$
County (FIPS county code; I - 3; nnn)

Mile marker (I - 11; nnn.nnn) $\mathbf{0 0 3 4 4 0}$

Road Name (I - 7): -

Vicinity (I - 9) 0.2 MI S JCT. VT $30 \mathrm{~S}$

Hydrologic Unit Code: $\underline{\mathbf{0 1 0 8 0 1 0 7}}$

Longitude (i - 17; nnnnn.n) $\mathbf{7 2 4 4 2}$

\section{Select Federal Inventory Codes}

FHWA Structure Number (I - 8) 20001300801309

Maintenance responsibility $(I-21 ; n n) \quad 01$

Year built (I - 27; YYYY) 1929

Average daily traffic, ADT (I - 29; nnnnnn) 001140

Year of ADT (I - 30; YY) $\mathbf{9 2}$

Opening skew to Roadway $(I-34 ; n n) \quad \mathbf{0 0}$

Operational status $(I-41 ; X) \quad \mathbf{P}$

Structure type (I- 43; nnn) $\mathbf{3 1 0}$

Approach span structure type (I - 44; nnn) $\mathbf{3 0 2}$

Number of spans (I - 45; nnn) $\mathbf{0 0 1}$

Number of approach spans (I - 46; nnnn) $\mathbf{0 0 0 2}$

Comments:

The structural inspection report of 11/04/93 indicates the structure is a steel thru-truss type bridge with steel beam approach spans and an asphalt road surface. Both abutments are concrete with skeletal type walls. The right abutment has some random minor rust stains and spalls. The left abutment has a few more cracks than the right abutment, but overall the concrete appears sound. Both solid pier stems have some random minor cracks, stains, and spalls. The footings are not in view. The waterway has a fairly straight alignment through the structure. It is diverted upstream slightly by a large gravel point bar with heavy vegetation growing along it, upstream of the right pier. (Continued, page 32) 


\section{Bridge Hydrologic Data}

Is there hydrologic data available? $\underline{\mathbf{Y}}$ if No, type ctrl- $n$ h VTAOT Drainage area $\left(m i^{2}\right): \underline{\mathbf{2 3 3 . 8}}$

Terrain character: Mountainous

Stream character \& type: Stream flow controlled by U.S. Army Corp of Engineers dam. The dams dampen rise of flashy tributaries below Ball Mountain reservoir.

Streambed material: Deep, dense, sandy gravel covered by boulder layer

$\begin{array}{lllll}\text { Discharge Data (cfs): } & Q_{2.33} \frac{\mathbf{3 3 5 0}}{\mathbf{1 3 0 0 0}} & \mathrm{Q}_{10} \frac{\mathbf{7 0 0 0}}{\mathrm{Q}_{50}} & \mathrm{Q}_{25} 1 \mathbf{1 0 0 0 0} \\ & \mathrm{Q}_{100} & \mathbf{1 6 0 0 0} & \mathrm{Q}_{500}\end{array}$

Record flood date $(M M / D D / Y Y): \underline{11} / \ldots$

Estimated Discharge (cfs): $\underline{\mathbf{2 6 0 0 0}}$ Velocity at Q $\underline{\mathbf{2 5}}$ (ft/s):

Ice conditions (Heavy, Moderate, Light): Heavy_Debris (Heavy, Moderate, Light): Moderate

The stage increases to maximum highwater elevation (Rapidly, Not rapidly): Not rapidly

The stream response is (Flashy, Not flashy): Not flashy

Describe any significant site conditions upstream or downstream that may influence the stream's

stage: Uncontrolled tributaries below the Ball Mountain reservoir are flashy. Dam operations dampen rise.

Watershed storage area (in percent): $1.2 \%$

The watershed storage area is: $\mathbf{3}$ (1-mainly at the headwaters; 2- uniformly distributed; 3-immediatly upstream oi the site)

Water Surface Elevation Estimates for Existing Structure:

\begin{tabular}{|l|l|c|c|l|l|}
\hline Peak discharge frequency & $Q_{2.33}$ & $Q_{10}$ & $Q_{25}$ & $Q_{50}$ & $Q_{100}$ \\
Water surface elevation $(f t))$ & $\mathbf{5 4 4 . 1 8}$ & $\mathbf{5 4 6 . 4 6}$ & $\mathbf{5 4 7 . 5 3}$ & $\mathbf{5 4 8 . 4 1}$ & $\mathbf{5 4 9 . 1 5}$ \\
Velocity $(f t / s e c)$ & $\mathbf{4 . 0 4}$ & $\mathbf{5 . 5 6}$ & $\mathbf{6 . 7 7}$ & $\mathbf{7 . 8 4}$ & $\mathbf{8 . 8 2}$ \\
\hline
\end{tabular}

Long term stream bed changes: The above water surface elevations are in NGVD

Is the roadway overtopped below the $\mathrm{Q}_{100}$ ? (Yes, No, Unknown): $\mathbf{N} \quad$ Frequency: -

Relief Elevation $(f t)$ :

Discharge over roadway at $\mathrm{Q}_{100}\left(\mathrm{ft}^{3} / \mathrm{sec}\right)$ : -

Are there other structures nearby? (Yes, No, Unknown): $\underline{\mathbf{Y}}$ Upstream distance (miles): 1.35 Town: If No or Unknown, type ctrl-n os

Highway No. : VT 30 Structure No. : 29 Year Built:

Clear span (ft): $\underline{\mathbf{2 0 4 . 0}}$ Clear Height $(f t): \underline{\mathbf{4 0 . 0}}$ Full Waterway $\left(f t^{2}\right): \underline{-}$ 
Downstream distance (miles): $\mathbf{3 . 8}$ Town: Year Built:

Highway No. : DAM Structure No. : Structure Type:

Clear span $(f t):$ Clear Height $(f t)$ : Full Waterway $\left(f^{2}\right)$ :

Comments:

There is minor scour at the left and right piers. The streambed consists of stone and gravel with some boulders. The downstream structure is the Townsend dam maintained and operated by the U.S. Army Corp of Engineers.

Bid let date for replacement project 11/30/96.

\section{USGS Watershed Data}

Watershed Hydrographic Data

Drainage area (DA) $227.37 \mathrm{mi}^{2}$ Lake and pond area $\mathbf{2 . 6 5}$ $\mathrm{mi}^{2}$

Watershed storage (ST) 1.16

Bridge site elevation $\mathbf{5 6 1} \mathrm{ft}$ $\%$

Main channel length $\mathbf{2 7 . 7 9}$ mi

$10 \%$ channel length elevation $\quad \mathbf{6 4 3}$ $\mathrm{ft} \quad 85 \%$ channel length elevation $\mathrm{ft}$

Main channel slope (S) 38.72 $\mathrm{ft} / \mathrm{mi}$

Watershed Precipitation Data

Average site precipitation in Average headwater precipitation in

Maximum 2yr-24hr precipitation event $(124,2)$ in

Average seasonal snowfall (Sn) $\mathrm{ft}$ 


\section{Bridge Plan Data}

Are plans available? $\underline{\mathbf{Y}}$ If no, type ctrl-n $p / \quad$ Date issued for construction (MM/YYYY): $\underline{\mathbf{0 8}} / \mathbf{1 9 2 8}$ Project Number FR $63 \mathrm{~A}$ Minimum channel bed elevation: $\mathbf{8 5 . 0}$

Low superstructure elevation: USLAB $\underline{106.57}$ DSLAB $\underline{106.57}$ USRAB $\underline{\text { 106.58 DSRAB }}$ 106.58 Benchmark location description:

NO BENCHMARK LOCATION INFORMATION.

Reference Point (MSL, Arbitrary, Other): Arbitrary $\quad$ Datum (NAD27, NAD83, Other): Arbitrary Foundation Type: 1 (1-Spreadfooting; 2-Pile; 3- Gravity; 4-Unknown)

If 1: Footing Thickness $\mathbf{3 . 0 *} \quad$ Footing bottom elevation: $\mathbf{8 0 . 5 7}$

If 2: Pile Type: ___ (1-Wood; 2-Steel or metal; 3-Concrete) Approximate pile driven length:

If 3: Footing bottom elevation:

Is boring information available? $\mathbf{N}$ If no, type ctrl-n bi Number of borings taken: -

Foundation Material Type: $\mathbf{3}$ (1-regolith, 2-bedrock, 3-unknown)

Briefly describe material at foundation bottom elevation or around piles:

NO FOUNDATION MATERIAL INFORMATION.

\section{Comments:}

Left pier top elevation: 106.87 bottom of footing: 76.10 . Right pier top elevation: 106.89 , bottom of footing: 76.12. Both piers have a 3 foot thick footing.

*The footing thickness shown above is on the right abutment. The left abutment footing is about four feet thick. Other points shown with elevations are: 1) the point on the roadway at the right abutment approximately 40 feet to right of right edge of water, elevation 109.8. 2) The roadway surface at the right pier, elevation $110.11,3$ ) the roadway surface at left pier, elevation 110.09 , and 4 ) the roadway surface at the left abutment approximately 40 feet to left of left edge of water, elevation 109.79. 


\section{Cross-sectional Data}

Is cross-sectional data available? Yes If no, type ctrl-n xs

Source (FEMA, VTAOT, Other)? FEMA

Comments: The station and elevation measurements are in feet.

Lpier and Rpier are defined as the left and right bottom edges of the piers.

Elevations are in NGVD.

\begin{tabular}{|l|l|l|l|l|l|l|l|l|l|l|l|}
\hline Station & $\mathbf{7 2 0}$ & $\mathbf{7 4 2}$ & $\mathbf{7 5 5 . 7}$ & $\mathbf{7 6 0}$ & $\mathbf{7 9 2}$ & $\mathbf{8 2 7}$ & $\mathbf{8 7 3}$ & $\mathbf{9 1 8}$ & $\mathbf{9 2 2 . 3}$ & $\mathbf{9 3 3}$ & $\mathbf{9 5 7 . 5}$ \\
\hline Feature & LAB & - & Lpier1 & Rpier1 & - & - & - & Lpier2 & Rpier2 & - & RAB \\
\hline $\begin{array}{l}\text { Low cord } \\
\text { elevation }\end{array}$ & $\mathbf{5 5 8 . 1}$ & $\mathbf{5 5 8 . 1}$ & $\mathbf{5 5 8 . 1}$ & $\mathbf{5 5 8 . 1}$ & $\mathbf{5 5 8 . 1}$ & $\mathbf{5 5 8 . 1}$ & $\mathbf{5 5 8 . 1}$ & $\mathbf{5 5 8 . 1}$ & $\mathbf{5 5 8 . 1}$ & $\mathbf{5 5 8 . 1}$ & $\mathbf{5 5 8 . 1}$ \\
\hline $\begin{array}{l}\text { Bed } \\
\text { elevation }\end{array}$ & $\mathbf{5 5 3 . 5}$ & $\mathbf{5 4 1 . 6}$ & $\mathbf{5 3 8 . 5}$ & $\mathbf{5 3 8}$ & $\mathbf{5 3 9 . 1}$ & $\mathbf{5 3 9 . 4}$ & $\mathbf{5 4 0 . 9}$ & $\mathbf{5 3 6 . 9}$ & $\mathbf{5 3 7 . 4}$ & $\mathbf{5 4 4 . 1}$ & $\mathbf{5 5 4 . 4}$ \\
\hline $\begin{array}{l}\text { Low cord to } \\
\text { bed length }\end{array}$ & $\mathbf{4 . 6}$ & $\mathbf{1 6 . 5}$ & $\mathbf{1 9 . 6}$ & $\mathbf{2 0 . 1}$ & $\mathbf{1 9}$ & $\mathbf{1 8 . 7}$ & $\mathbf{1 7 . 2}$ & $\mathbf{2 1 . 2}$ & $\mathbf{2 0 . 7}$ & $\mathbf{1 4}$ & $\mathbf{3 . 7}$ \\
\hline Station & - & - & - & - & - & - & - & - & - & - & - \\
\hline Feature & - & - & - & - & - & - & - & - & - & - & - \\
\hline $\begin{array}{l}\text { Low cord } \\
\text { elevation }\end{array}$ & - & - & - & - & - & - & - & - & - & - & - \\
\hline $\begin{array}{l}\text { Bed } \\
\text { elevation }\end{array}$ & - & - & - & - & - & - & - & - & - & - & - \\
\hline $\begin{array}{l}\text { Low cord to } \\
\text { bed length }\end{array}$ & - & - & - & - & - & - & - & - & - & - & - \\
\hline
\end{tabular}

Source (FEMA, VTAOT, Other)?

Comments: -

\begin{tabular}{|l|l|l|l|l|l|l|l|l|l|l|l|}
\hline Station & - & - & - & - & - & - & - & - & - & - & - \\
\hline Feature & - & - & - & - & - & - & - & - & - & - & - \\
\hline $\begin{array}{l}\text { Low cord } \\
\text { elevation }\end{array}$ & - & - & - & - & - & - & - & - & & - & - \\
\hline $\begin{array}{l}\text { Bed } \\
\text { elevation }\end{array}$ & - & - & - & - & - & - & - & - & - & - & - \\
\hline $\begin{array}{l}\text { Low cord to } \\
\text { bed length }\end{array}$ & - & - & - & - & - & - & - & - & - & - & - \\
\hline Station & - & - & - & - & - & - & - & - & - & - & - \\
\hline Feature & - & - & - & - & - & - & - & - & - & - & - \\
\hline $\begin{array}{l}\text { Low cord } \\
\text { elevation }\end{array}$ & - & - & - & - & - & - & - & - & - & - & - \\
\hline $\begin{array}{l}\text { Bed } \\
\text { elevation }\end{array}$ & - & - & - & - & - & - & - & - & - & - & - \\
\hline $\begin{array}{l}\text { Low cord to } \\
\text { bed length }\end{array}$ & - & - & - & - & - & - & - & - & - & - & - \\
\hline
\end{tabular}




\section{APPENDIX E: \\ LEVEL I DATA FORM}


U. S. Geological Survey

Bridge Field Data Collection and Processing Form

Qa/Qc Check by: $\underline{\mathbf{R B}}$ Date: $09 / 26 / 96$

\section{A. General Location Descriptive}

1. Data collected by (First Initial, Full last name) $\mathbf{J}$. DEGNAN

2. Highway District Number $\mathbf{0 2}$

Mile marker 003440

County 025 WINDHAM

Town 36175 JAMAICA

Waterway (I - 6) WEST RIVER

Route Number VT100

Road Name -

Hydrologic Unit Code: $\mathbf{0 1 0 8 0 1 0 7}$

3. Descriptive comments:

This is a steel thru-truss type bridge located 0.2 miles south of the junction with VT 30 South.

\section{B. Bridge Deck Observations}
4. Surface cover... LBUS 4
RBUS 6
LBDS 4
RBDS 4
Overall 4

(2b us, ds,lb,rb: 1- Urban; 2- Suburban; 3- Row crops; 4- Pasture; 5- Shrub- and brushland; 6- Forest; 7- Wetland)
5. Ambient water surface... US 2
UB 2
DS $\underline{2}$
(1- pool; 2- riffle)

6. Bridge structure type 2 (1- single span; 2- multiple span; 3- single arch; 4- multiple arch; 5-cylindrical culvert; 6- box culvert; or 7- other)

7. Bridge length 246 (feet)

\section{Road approach to bridge:}
8. LB 0
RB 2
( 0 even, 1- lower, 2- higher)
9. LB_
RB 1
(1- Paved, 2- Not paved)

10. Embankment slope (run / rise in feet / foot)

$$
\text { US left }
$$

0.0:1

US right

0.0:1

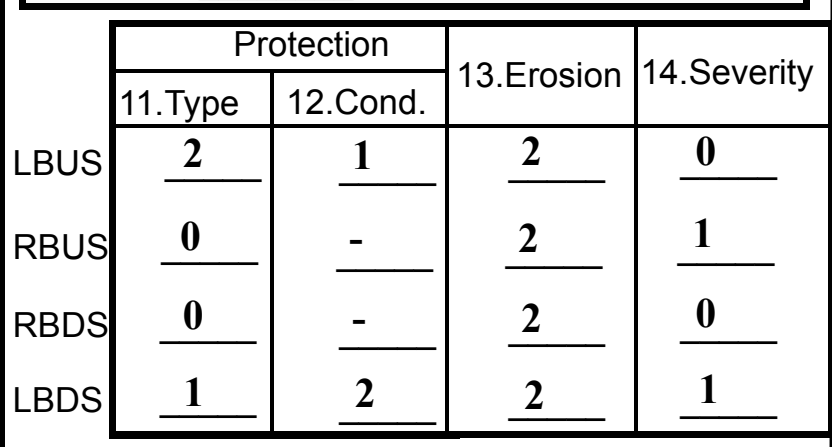

Bank protection types: 0- none; 1- $<12$ inches;

2- < 36 inches; 3- < 48 inches;

4- < 60 inches; 5- wall / artificial levee

Bank protection conditions: 1- good; 2- slumped;

3- eroded; 4- failed

Erosion: 0 - none; 1- channel erosion; 2

road wash; 3- both; 4- other

Erosion Severity: 0 - none; 1- slight; 2- moderate; 3- severe

Span length 161 (feet) Bridge width $\underline{21.8}$ (feet)

\section{Channel approach to bridge (BF):}

15. Angle of approach: $\mathbf{0}$

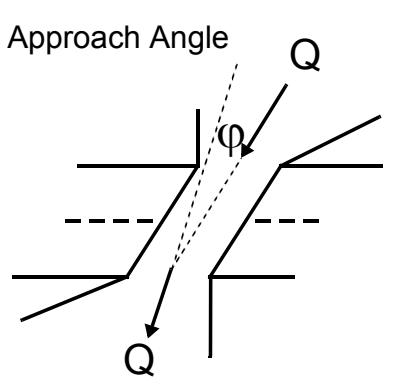

17. Channel impact zone 1 :

Where? LB $(L B, R B)$

Range? 270 feet $\underline{\mathbf{U S}}$

Channel impact zone 2:

Where? RB (LB, RB)

Range? $\underline{35}$ feet $\underline{\text { US }}$

Impact Severity: 0- none to very slight; 1-Slight; 2- Moderate; 3- Severe
16. Bridge skew: 5 Bridge Skew Angle

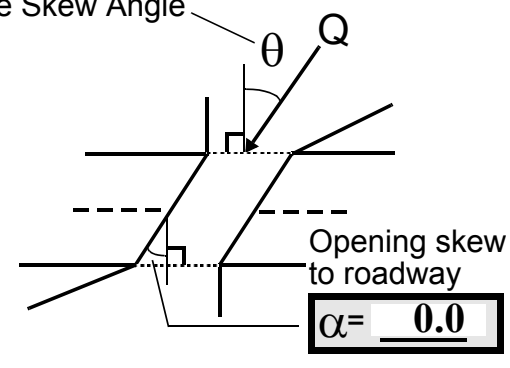

\section{Exist? $\underline{\mathbf{Y}}(\mathrm{Y}$ or $N)$}

Severity 1

(US, UB, DS) to $\underline{\mathbf{2 6}}$ feet $\underline{\mathrm{DS}}$

Exist? $\underline{\mathbf{Y}}(\mathrm{Y}$ or $N)$

Severity 2

$B, D S)$ to 0 feet $\underline{\text { US }}$ 
18. Bridge Type: $\mathbf{1 b}$

1a- Vertical abutments with wingwalls

$1 \mathrm{~b}$ - Vertical abutments without wingwalls

2- Vertical abutments and wingwalls, sloping embankment Wingwalls perpendicular to abut. face

3- Spill through abutments

4- Sloping embankment, vertical wingwalls and abutments

Wingwall angle less than $90^{\circ}$.
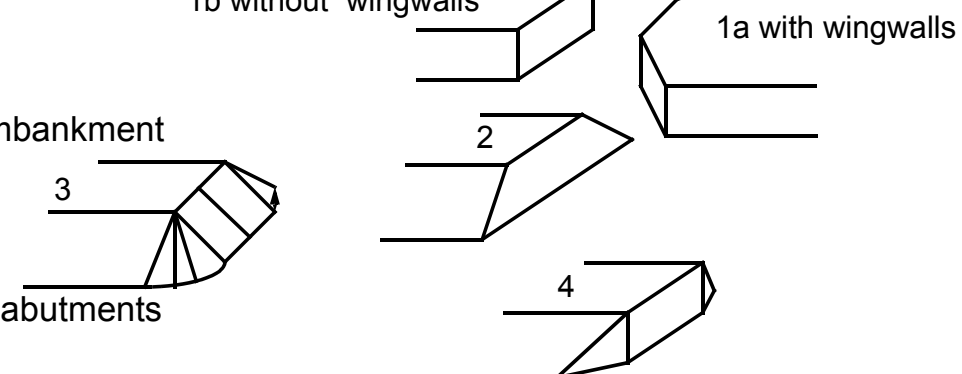

19. Bridge Deck Comments (surface cover variations, measured bridge and span lengths, bridge type variations, approach overflow width, etc.)

7. Values are from the VT AOT files. Measured bridge length is $245 \mathrm{ft}$., span length is $158 \mathrm{ft}$., and bridge width is $21.8 \mathrm{ft}$.

4. All of the banks are heavily wooded but the predominant surface cover just beyond the banks is pasture except on the US right bank where there is a house and lawn surrounded by forest.

17. Both of the channel impact zones are a result of the US bar dividing the flow. The right bank is impacted at the spill-through slope of the right abutment. The spill-through protection directs the flow toward the pier.

\section{Upstream Channel Assessment}

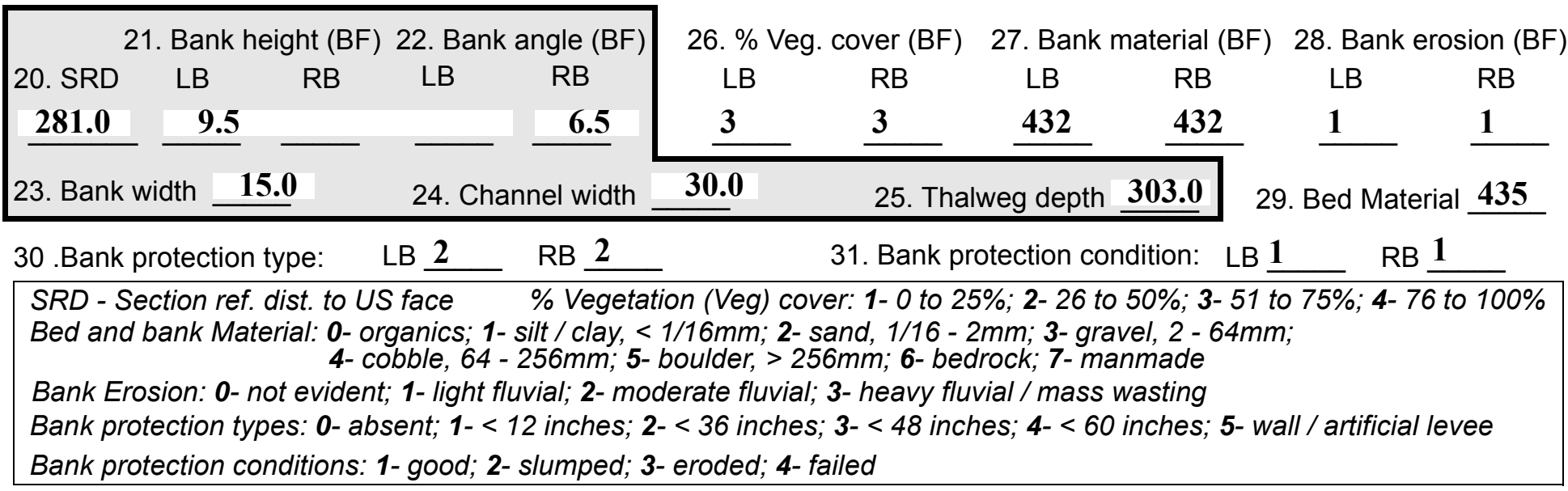

32. Comments (bank material variation, minor inflows, protection extent, etc.):

The right and left bank protection is part of the spill-through abutment protection. It is dumped stone extending from $35 \mathrm{ft}$. US to the US bridge face on both banks. 
33.Point/Side bar present? $\mathbf{N}(Y$ or $N$. if $N$ type ctrl-n pb)34. Mid-bar distance: -

35. Mid-bar width: -

36. Point bar extent: feet (US, UB) to feet (US, UB, DS) positioned $\%$ LB to $\%$ RB

37. Material: -

38. Point or side bar comments (Circle Point or Side; Note additional bars, material variation, status, etc.):

An island has formed upstream of the right pier. The island width is 190 feet and it is located from 390 feet US to 30 feet DS. The island grades from cobble to sand material towards the center. At high flow there is a channel around the right bank side of the island. It is heavily vegetated with grass and small trees. High water marks indicate flow overtopping the island.

39. Is a cut-bank present? $\underline{\mathbf{Y}}$ (Y or if $N$ type ctrl-n cb) 40. Where? $\underline{\mathbf{L B}}$ (LB or RB)

41. Mid-bank distance: $180 \quad$ 42. Cut bank extent: $\underline{\mathbf{2 4 0}}$ feet $\underline{\mathrm{US}}$ (US, UB) to $\underline{\mathbf{1 3 0}}$ feet $\underline{\text { US }}$ (US, UB, DS)

43. Bank damage: 1 (1- eroded and/or creep; 2- slip failure; 3- block failure)

44. Cut bank comments (eg. additional cut banks, protection condition, etc.):

\section{Is channel scour present? $\quad \mathbf{Y}$ (Y or if $N$ type ctrl-n cs) $\quad$ 46. Mid-scour distance: $\underline{\mathbf{0}}$}

47. Scour dimensions: Length $\underline{100}$ Width $\underline{40}$ Depth : $\underline{5} \quad$ Position $\underline{60} \%$ LB to $\underline{80} \%$ RB

48. Scour comments (eg. additional scour areas, local scouring process, etc.):

The scour hole is $100 \mathrm{ft}$. long and $40 \mathrm{ft}$. wide.

\section{Are there major confluences? N}

51. Confluence 1: Distance Confluence 2: Distance 52. Enters on Enters on - $\quad(L B$ or $R B)$ 54. Confluence comments (eg. confluence name):

\section{NO MAJOR CONFLUENCES}

50. How many? -
53. Type- (1-perennial; 2- ephemeral)
Type - (1-perennial; 2- ephemeral)

\section{Under Bridge Channel Assessment}

55. Channel restraint (BF)? LB 2

56. Height (BF)
LB RB
$\mathbf{2 7 0 . 0}$
58. Bank width (BF) -
(1- natural bank; 2- abutment; 3- artificial levee)

Bed and bank Material: 0- organics; 1- silt / clay, < 1/16mm; 2- sand, 1/16 - 2mm; 3- gravel, 2 - 64mm; 4- cobble, 64 - 256mm; 5- boulder, > 256mm; 6- bedrock; 7- manmade

Bank Erosion: 0- not evident; 1- light fluvial; 2- moderate fluvial; 3- heavy fluvial / mass wasting

64. Comments (bank material variation, minor inflows, protection extent, etc.):

435

The point bar is sand under the bridge. The abutment walls are concrete skeletal type walls with dumped stone protection in front of them acting as a spill-through abutment slope. 
65. Debris and Ice Is there debris accumulation?

(Yor $N)$ 66. Where? $\underline{Y}$

(1- Upstream; 2- At bridge; 3- Both)

67. Debris Potential $\underline{3}$

( 1- Low; 2- Moderate; 3- High)

68. Capture Efficiency 2

(1-Low; 2- Moderate; 3- High)

69. Is there evidence of ice build-up? 2

Ice Blockage Potential $\underline{Y}$

(1-Low; 2- Moderate; 3- High)

70. Debris and Ice Comments:

2

There were debris caught on the US side bar. Also debris were blocking flow between the right pier and the right abutment spill-through protection.

\begin{tabular}{|l|c|c|c|c|c|c|c|c|}
\hline Abutments & $\begin{array}{c}\text { 71. Attack } \\
\angle \text { (BF) }\end{array}$ & $\begin{array}{c}72 \text {. Slope } \angle \\
\text { (Qmax) }\end{array}$ & $\begin{array}{c}\text { 73. Toe } \\
\text { loc. (BF) }\end{array}$ & $\begin{array}{c}\text { 74. Scour } \\
\text { Condition }\end{array}$ & $\begin{array}{c}75 . \text { Scour } \\
\text { depth }\end{array}$ & $\begin{array}{c}\text { 76. Exposure } \\
\text { depth }\end{array}$ & 77. Material & 78. Length \\
\hline LABUT & & $\mathbf{5}$ & $\mathbf{9 0}$ & $\mathbf{0}$ & $\mathbf{0}$ & - & - & $\mathbf{9 0 . 0}$ \\
\hline RABUT & $\mathbf{1}$ & $\mathbf{0}$ & $\mathbf{9 0}$ & & & $\mathbf{2}$ & $\mathbf{0}$ & $\mathbf{2 3 7 . 0}$ \\
\hline
\end{tabular}

Pushed: $L B$ or RB

Toe Location (Loc.): 0- even, 1- set back, 2- protrudes

Scour cond.: 0- not evident; 1- evident (comment); 2- footing exposed; 3-undermined footing; 4- piling exposed; 5- settled; 6- failed

Materials: 1- Concrete; 2- Stone masonry or drywall; 3- steel or metal; 4- wood

79. Abutment comments (eg. undermined penetration, unusual scour processes, debris, etc.):

$-$

1

80. Wingwalls:

Exist? Material? Scour Scour Exposure Angle? Length? Condition? depth? depth?

USLWW:

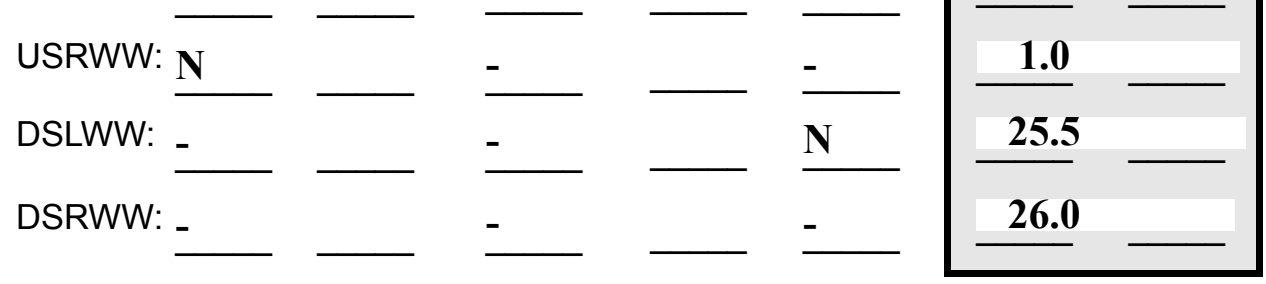

Wingwall materials: 1- Concrete; 2- Stone masonry or drywall; 3- steel or metal; 4- wood

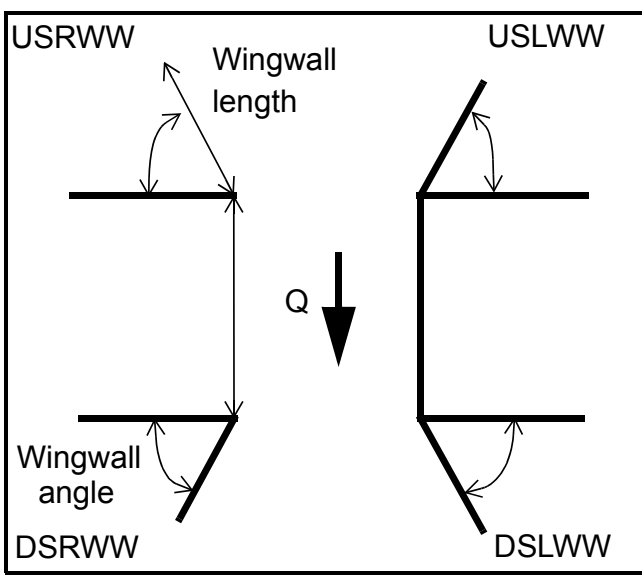

82. Bank / Bridge Protection:

\begin{tabular}{|l|l|l|l|l|l|l|l|c|}
\hline Location & USLWW & USRWW & LABUT & RABUT & LB & RB & DSLWW & DSRWW \\
\hline Type & - & - & N & - & - & - & $\mathbf{2}$ & $\mathbf{1}$ \\
\hline Condition & N & - & - & - & - & - & $\mathbf{1}$ & $\mathbf{1}$ \\
\hline Extent & - & - & - & - & - & $\mathbf{2}$ & $\mathbf{2}$ & - \\
\hline
\end{tabular}

Bank / Bridge protection types: 0- absent; 1- < 12 inches; 2- < 36 inches; 3- < 48 inches; 4- < 60 inches; 
83. Wingwall and protection comments (eg. undermined penetration, unusual scour processes, etc.):

-
-
-
-
-
-
-

\section{Piers:}

84. Are there piers? _ _ (Y or if $N$ type ctrl-n pr)

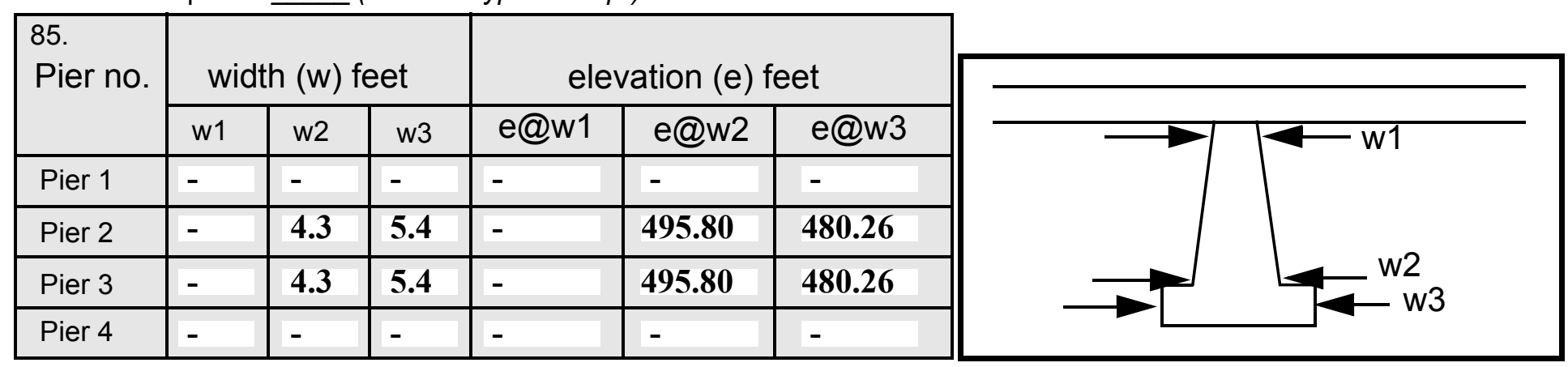

\begin{tabular}{|l|l|l|l|l|}
\hline Level 1 Pier Descr. & \multicolumn{1}{|c|}{1} & \multicolumn{1}{|c|}{2} & \multicolumn{1}{|c|}{4} \\
\hline 86. Location (BF) & & L & MC & $\mathbf{0}$ \\
\hline 87. Type & & $\mathbf{1}$ & $\mathbf{R}$ & - \\
\hline 88. Material & & $\mathbf{2}$ & $\mathbf{1}$ & - \\
\hline 89. Shape & & $\mathbf{3}$ & $\mathbf{2}$ & - \\
\hline 90. Inclined? & & $\mathbf{N}$ & $\mathbf{3}$ & - \\
\hline 91. Attack $\angle$ (BF) & & $\mathbf{5}$ & $\mathbf{N}$ & - \\
\hline 92. Pushed & & LB & $\mathbf{2 0}$ & - \\
\hline 93. Length (feet) & - & - & - & - \\
\hline 94. \# of piles & & UNK & LB & - \\
\hline 95. Cross-members & & $\mathbf{0}$ & UNK & - \\
\hline 96. Scour Condition & & $\mathbf{1}$ & $\mathbf{0}$ & - \\
\hline 97. Scour depth & Y & $\mathbf{3}$ & $\mathbf{1}$ & - \\
\hline 98. Exposure depth & MC & $\mathbf{0}$ & $\mathbf{5}$ & - \\
\hline
\end{tabular}

LFP, LTB, LB, MCL, MCM, MCR, RB, RTB, RFP

1- Solid pier, 2- column, 3- bent

1-Wood; 2-concrete; 3- metal; 4- stone

1- Round; 2- Square; 3- Pointed

Y-yes; $N$ - no

$L B$ or $R B$

0- none; 1- laterals; 2- diagonals; 3- both

0- not evident; 1- evident (comment);

2- footing exposed; 3- piling exposed;

4- undermined footing; 5- settled; 6- failed 
99. Pier comments (eg. undermined penetration, protection and protection extent, unusual scour processes, etc.):

-
-
-
-
-
-
-
-
-

100.

\section{E. Downstream Channel Assessment}

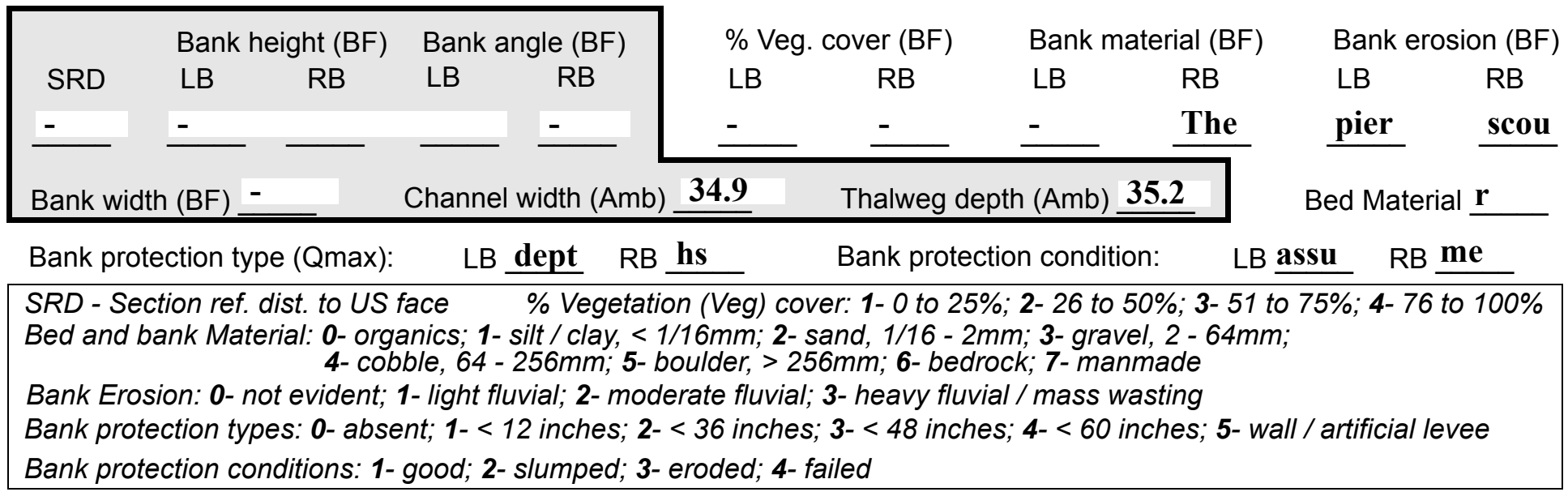

Comments (eg. bank material variation, minor inflows, protection extent, etc.):

a 1 foot deep thalweg. Pier 1 has scour on both sides with the maximum scour depth occurring at the upstream end on the right side. The hole surrounding pier 1 is $20 \mathrm{ft}$. wide and $30 \mathrm{ft}$. long. Pier 2 has scour on the left side only with the maximum scour depth located at the upstream end.

$\mathbf{0}$

101. Is a drop structure present? $\mathbf{0}$ ( $Y$ or $N$, if $N$ type ctrl-n ds) 102. Distance: __ feet 103. Drop: -_ feet 104. Structure material: 435 (1- steel sheet pile; 2- wood pile; 3- concrete; 4- other) 105. Drop structure comments (eg. downstream scour depth):

2

2

1

1

The protection on both the right and left banks is from $0 \mathrm{ft}$. DS to $20 \mathrm{ft}$. DS. 
Point bar extent: feet (US, UB, DS) to feet (US, UB, DS) positioned $\%$ LB to $\% \mathrm{RB}$

Material:

Point or side bar comments (Circle Point or Side; note additional bars, material variation, status, etc.):

$\mathbf{N}$

Is a cut-bank present? - (Y or if $N$ type ctrl-n $c b)$ Where? NO (LB or RB) Mid-bank distance: $\underline{\text { DR }}$ Cut bank extent: $\underline{\mathbf{O P}}$ feet $\underline{\mathbf{S T}}$ (US, UB, DS) to $\underline{\mathbf{R U C}}$ feet $\underline{\mathbf{T U}}$ (US, UB, DS)

Bank damage: $\underline{\mathbf{R E}}$ (1-eroded and/or creep; 2- slip failure; 3- block failure)

Cut bank comments (eg. additional cut banks, protection condition, etc.):

Is channel scour present? ( $Y$ or if $N$ type ctrl-n $c s)$

Mid-scour distance: $\underline{\mathbf{Y}}$

Scour dimensions: Length $\mathbf{7 0}$ Width $\mathbf{3 5}$ Depth: $\mathbf{5 0}$

Positioned DS \%LB to $\underline{\mathbf{1 1 5}} \%$ RB

Scour comments (eg. additional scour areas, local scouring process, etc.):

DS

80

100

321

Are there major confluences? Th ( $Y$ or if $N$ type ctrl-n $m c$ )

How many? ere

Confluence 1: Distance is an

Enters on addi ( $L B$ or $R B$ )

Type tion (1- perennial; 2- ephemeral)

Confluence 2: Distance al

Enters on side $(L B$ or $R B)$

Type bar (1- perennial; 2- ephemeral)

Confluence comments (eg. confluence name):

with gravel and cobble material extending from $460 \mathrm{ft}$. DS to $1400 \mathrm{ft}$. DS with a mid-bar distance of $500 \mathrm{ft}$. DS and a width of $40 \mathrm{ft}$. It is positioned $45 \% \mathrm{LB}$ to $100 \% \mathrm{RB}$.

\section{F. Geomorphic Channel Assessment}

107. Stage of reach evolution

1- Constructed

2- Stable

3- Aggraded

4- Degraded

5- Laterally unstable

6- Vertically and laterally unstable 
108. Evolution comments (Channel evolution not considering bridge effects; See HEC-20, Figure 1 for geomorphic descriptors):

Y

LB

750

675

DS

800

DS

1

This cut bank is in line with the confluence entrance on the opposite bank. 


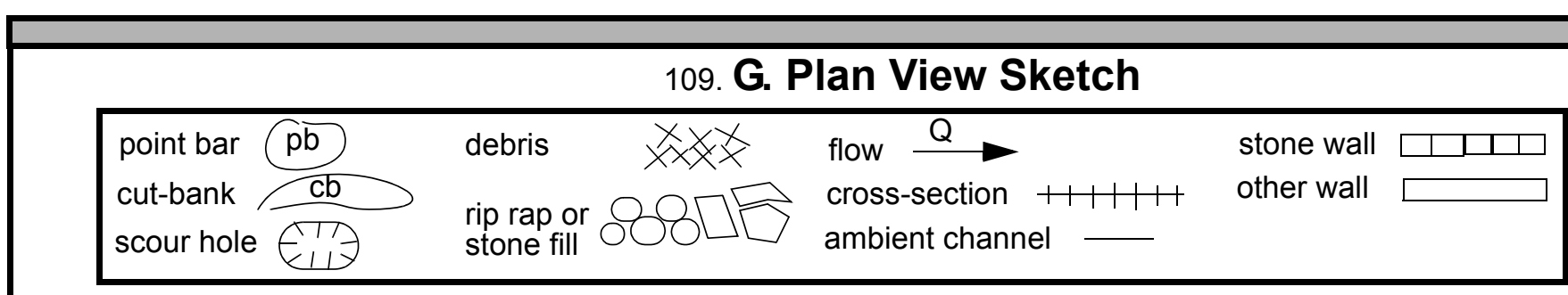


APPENDIX F:

SCOUR COMPUTATIONS 


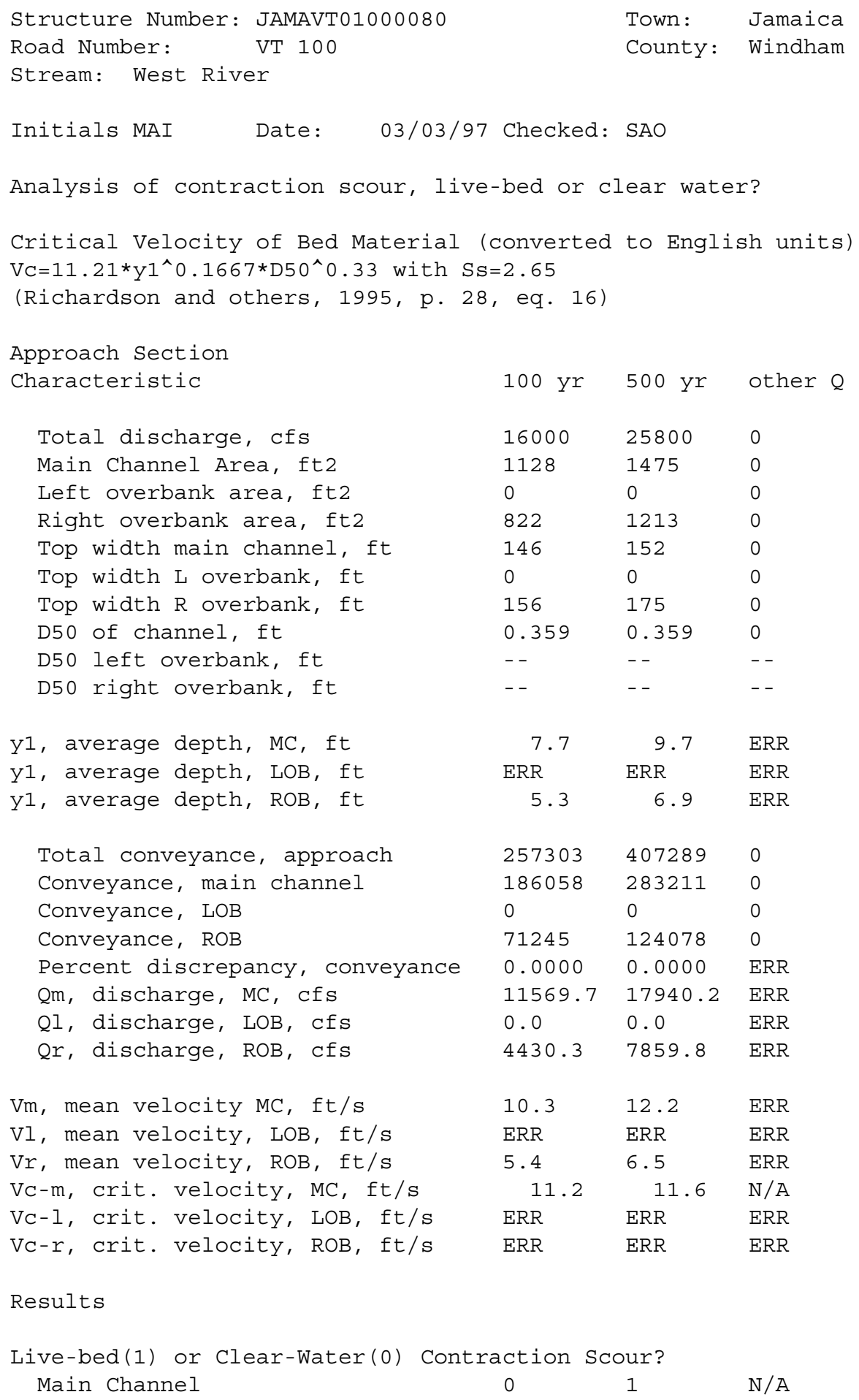




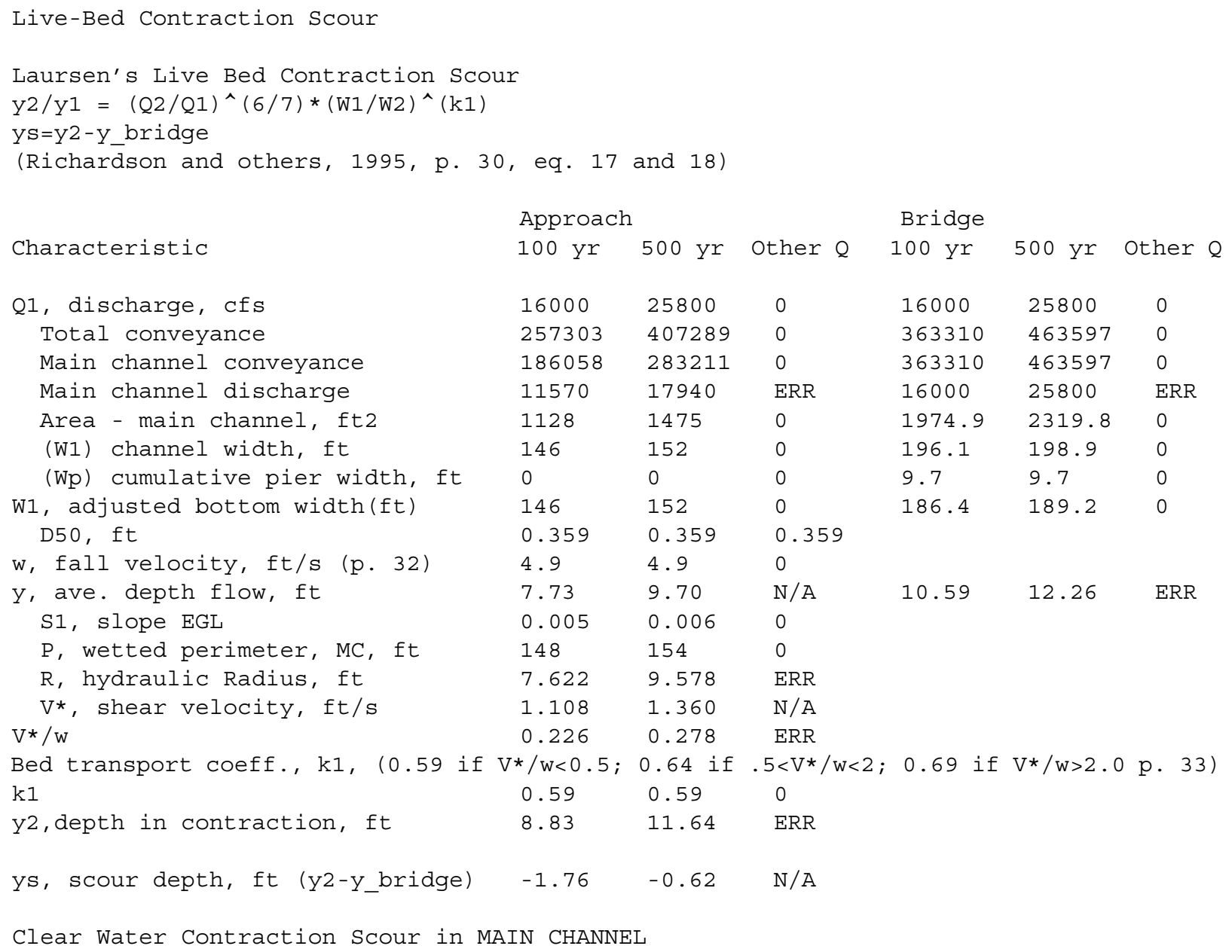




$\begin{array}{llll}\text { Q2, bridge MC discharge, ffs } & 16000 & 25800 & \text { ERR } \\ \text { Main channel area, ft2 } & 1975 & 2320 & 0 \\ \text { Main channel width (skewed), ft } & 196.1 & 198.9 & 0.0 \\ \text { Cum. width of piers in MC, ft } & 9.7 & 9.7 & 0.0 \\ \text { W, adjusted width, ft } & 186.4 & 189.2 & 0 \\ \text { Y_bridge (avg. depth at br.), ft } & 10.59 & 12.26 & \text { ERR } \\ \text { Dm, median (1.25*D50), ft } & 0.44875 & 0.44875 & 0 \\ \text { y2, depth in contraction,ft } & 7.07 & 10.51 & \text { ERR } \\ \text { ys, scour depth (y2-ybridge), ft } & -3.52 & -1.75 & \text { N/A }\end{array}$

$\begin{array}{llll}\text { ARMORING } & & & \\ \text { D90 } & 1.163 & 1.163 & 0 \\ \text { D95 } & 1.395 & 1.395 & 0 \\ \text { Critical grain size,DC, ft } & 0.3047 & 0.5398 & \text { ERR } \\ \text { Decimal-percent coarser than DC } & 0.572 & 0.38 & 0 \\ \text { Depth to armoring,ft } & 0.68 & 2.64 & \text { ERR }\end{array}$

Abutment scour

Froehlich's Abutment Scour

$\mathrm{Ys} / \mathrm{Y} 1=2.27 * \mathrm{~K} 1 * \mathrm{~K} 2 *\left(\mathrm{a}^{\prime} / \mathrm{Y} 1\right) \wedge 0.43 * \mathrm{Fr} 1 \wedge 0.61+1$

(Richardson and others, 1995, p. 48, eq. 28)

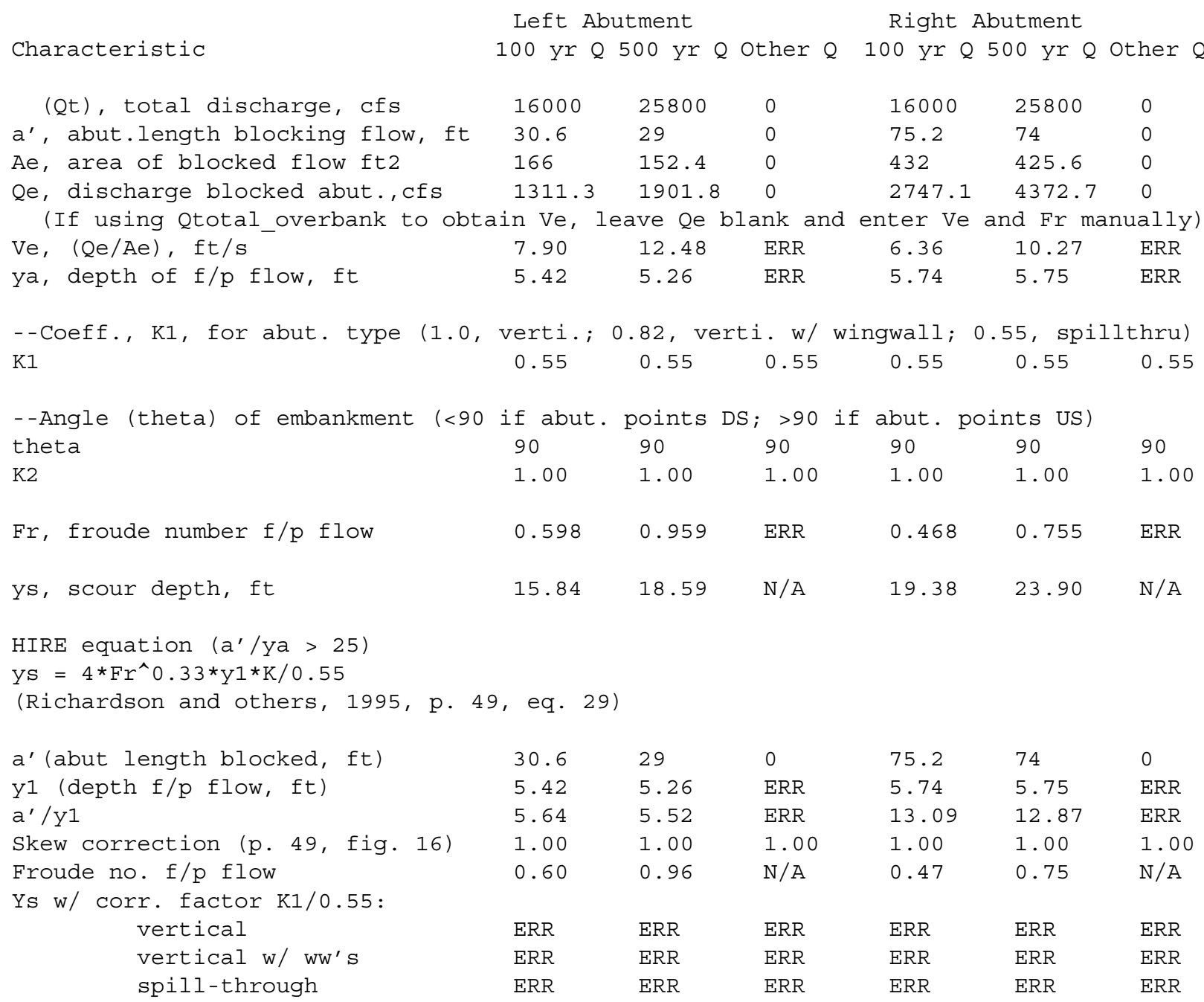




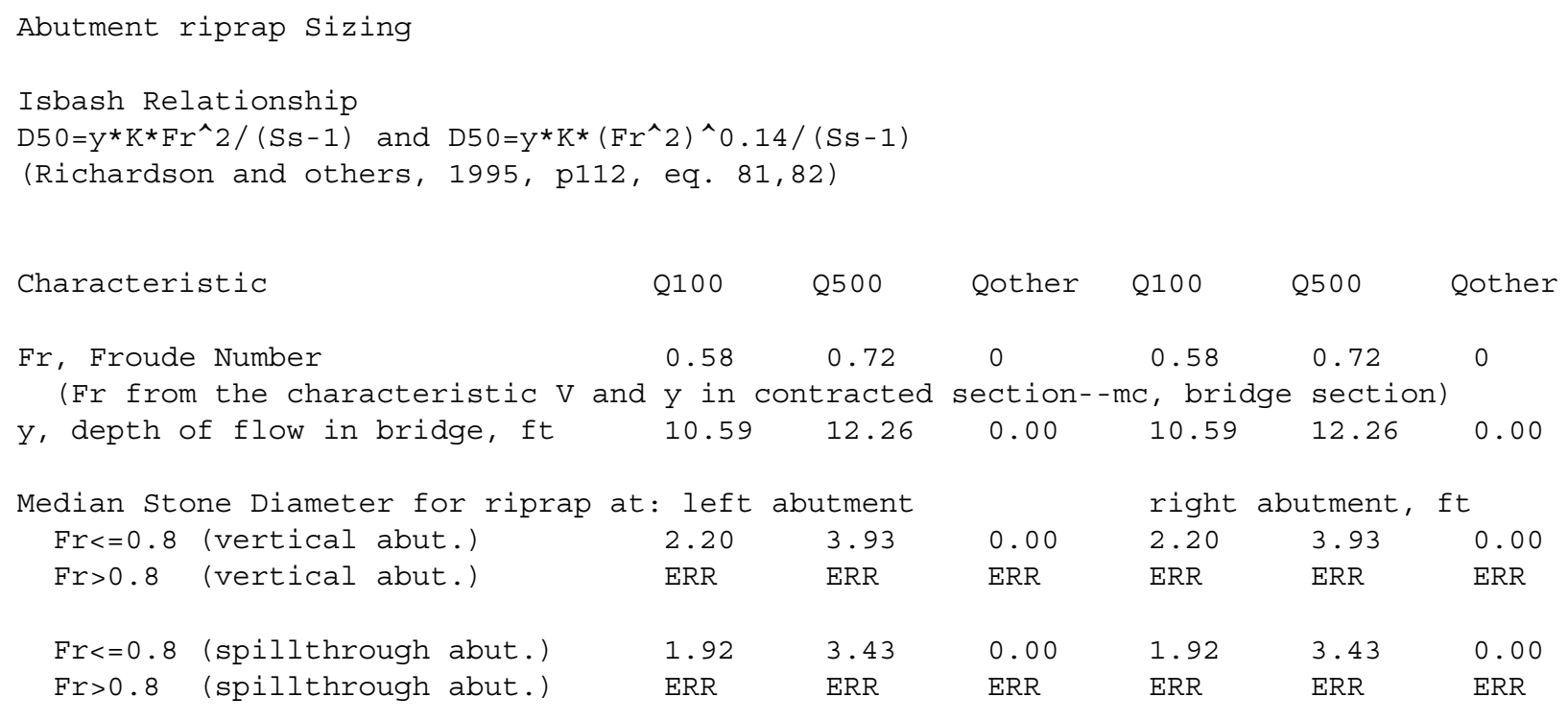

Pier Scour (both live-bed and clear water scour)

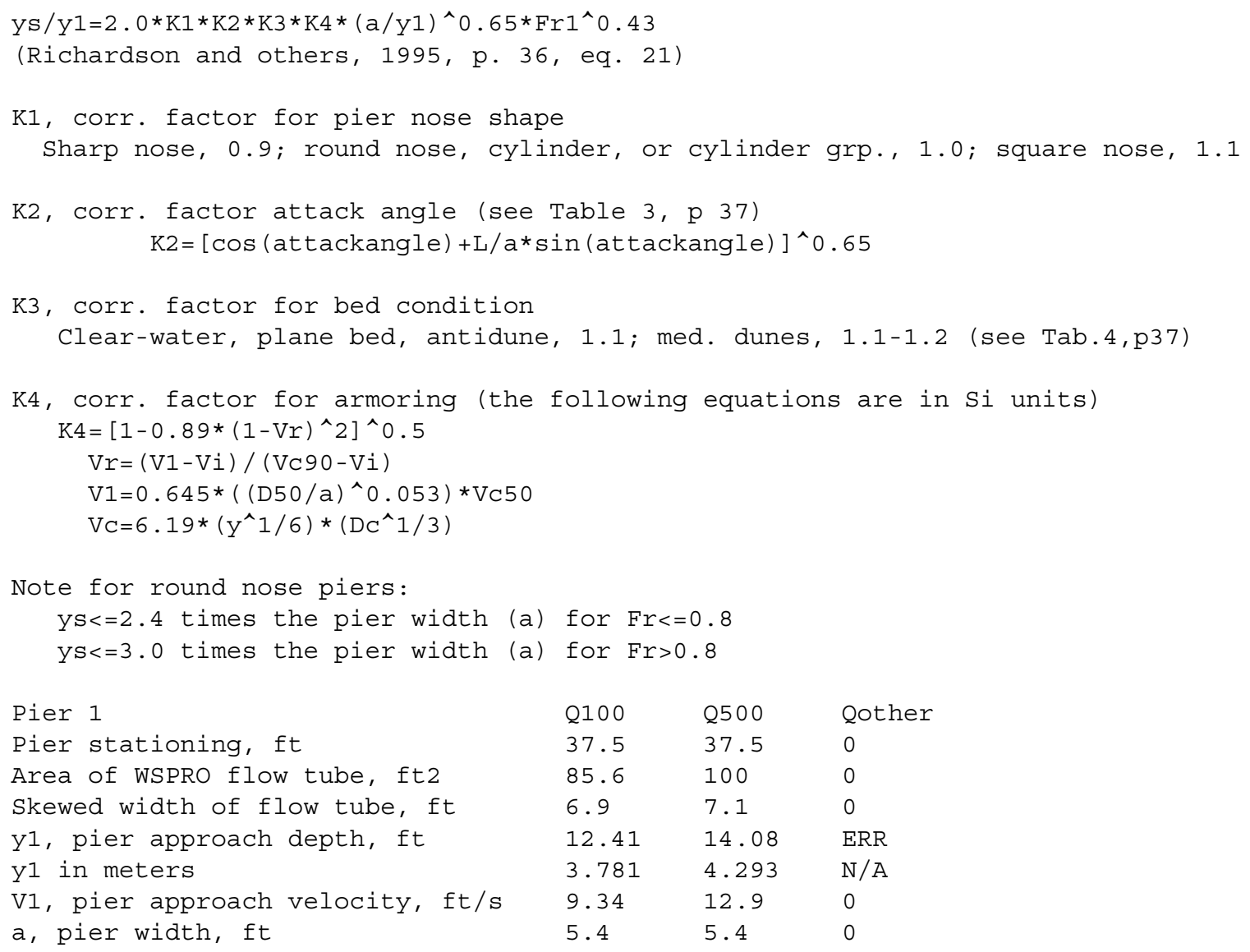




$\begin{array}{llll}\text { L, pier length, ft } & 34.9 & 34.9 & 0 \\ \text { Fr1, Froude number at pier } & 0.467 & 0.606 & \text { ERR } \\ \text { Pier attack angle, degrees } & 5 & 5 & 0 \\ \text { K1, shape factor } & 0.9 & 0.9 & 0 \\ \text { K2, attack factor } & 1.33 & 1.33 & \text { ERR } \\ \text { K3, bed condition factor } & 1.1 & 1.1 & 0 \\ \text { D50, ft } & 0.359 & 0.359 & 0 \\ \text { D50, m } & 0.1094 & 0.1094 & 0 \\ \text { D90, ft } & 1.163 & 1.163 & 0 \\ \text { D90, m } & 0.354 & 0.354 & 0 \\ \text { Vc50, critical velocity(D50), m/s } & 3.695 & 3.774 & \mathrm{~N} / \mathrm{A} \\ \text { VC90, critical velocity(D90), m/s } & 5.468 & 5.585 & \mathrm{~N} / \mathrm{A} \\ \text { Vi, incipient velocity,m/s } & 2.065 & 2.109 & \text { ERR } \\ \text { Vr, velocity ratio } & 0.230 & 0.524 & \text { ERR } \\ \text { K4, armor factor } & 0.69 & 0.89 & \mathrm{~N} / \mathrm{A} \\ \text { ys, scour depth (K4 applicable) ft } & 9.46 & 14.38 & \text { ERR } \\ \text { Ys, scour depth (K4 not applied) ft } & \text { ERR } & \text { ERR } & \text { ERR }\end{array}$

Pier Scour (both live-bed and clear water scour)

$\mathrm{Ys} / \mathrm{Y} 1=2.0 * \mathrm{~K} 1 * \mathrm{~K} 2 * \mathrm{~K} 3 * \mathrm{~K} 4 *(\mathrm{a} / \mathrm{Y} 1) \wedge 0.65 * \mathrm{Fr}^{\wedge} 0.43$

(Richardson and others, 1995, p. 36, eq. 21)

K1, corr. factor for pier nose shape

Sharp nose, 0.9; round nose, cylinder, or cylinder grp., 1.0; square nose, 1.1

K2, corr. factor attack angle (see Table 3, p 37)

$\mathrm{K} 2=\left[\cos (\text { attackangle })+\mathrm{L} / \mathrm{a}{ }^{*} \sin (\text { attackangle })\right]^{\wedge} 0.65$

K3, corr. factor for bed condition

Clear-water, plane bed, antidune, 1.1; med. dunes, 1.1-1.2 (see Tab.4,p37)

K4, corr. factor for armoring (the following equations are in si units)

$\mathrm{K} 4=\left[1-0.89 *(1-\mathrm{Vr})^{\wedge} 2\right]^{\wedge} 0.5$

$\mathrm{Vr}=(\mathrm{V} 1-\mathrm{Vi}) /(\mathrm{VC} 90-\mathrm{Vi})$

$\mathrm{V} 1=0.645 *((\mathrm{D} 50 / \mathrm{a}) \wedge 0.053) * \mathrm{VC} 50$

$\mathrm{VC}=6.19 *\left(\mathrm{y}^{\wedge} 1 / 6\right) *\left(\mathrm{DC}^{\wedge} 1 / 3\right)$

Note for round nose piers:

ys $<=2.4$ times the pier width (a) for Fr<=0.8

ys $<=3.0$ times the pier width (a) for Fr>0.8 


\begin{tabular}{|c|c|c|c|c|}
\hline Pier 2 & Q100 & Q500 & \multicolumn{2}{|l|}{ Qother } \\
\hline Pier stationing, ft & 200 & 200 & \multicolumn{2}{|l|}{0} \\
\hline Area of WSPRO flow tube, ft 2 & 85.6 & 100 & \multicolumn{2}{|l|}{0} \\
\hline Skewed width of flow tube, ft & 6.9 & 7.1 & \multicolumn{2}{|l|}{0} \\
\hline y1, pier approach depth, ft & 12.41 & 14.08 & \multicolumn{2}{|l|}{ ERR } \\
\hline y1 in meters & 3.781 & 4.293 & \multicolumn{2}{|l|}{$\mathrm{N} / \mathrm{A}$} \\
\hline V1, pier approach velocity, ft/s & 9.34 & 12.9 & \multicolumn{2}{|l|}{0} \\
\hline a, pier width, ft & 5.4 & 5.4 & \multicolumn{2}{|l|}{0} \\
\hline L, pier length, ft & 35.2 & 35.2 & \multicolumn{2}{|l|}{0} \\
\hline Fr1, Froude number at pier & 0.467 & 0.606 & \multicolumn{2}{|l|}{ ERR } \\
\hline Pier attack angle, degrees & 20 & 20 & \multicolumn{2}{|l|}{0} \\
\hline K1, shape factor & 0.9 & 0.9 & \multicolumn{2}{|l|}{0} \\
\hline K2, attack factor & 2.12 & 2.12 & \multicolumn{2}{|l|}{$\mathrm{ERR}$} \\
\hline K3, bed condition factor & 1.1 & 1.1 & \multicolumn{2}{|l|}{0} \\
\hline D50, ft & 0.359 & 0.359 & \multicolumn{2}{|l|}{0} \\
\hline D50, m & 0.1094 & 0.1094 & \multicolumn{2}{|l|}{0} \\
\hline D90, ft & 1.163 & 1.163 & \multicolumn{2}{|l|}{0} \\
\hline $\mathrm{D} 90, \mathrm{~m}$ & 0.354 & 0.354 & \multicolumn{2}{|l|}{0} \\
\hline Vc50, critical velocity (D50), m/s & 3.695 & 3.774 & \multicolumn{2}{|l|}{$\mathrm{N} / \mathrm{A}$} \\
\hline Vc 90 , critical velocity $(\mathrm{D} 90), \mathrm{m} / \mathrm{s}$ & 5.468 & 5.585 & \multicolumn{2}{|l|}{$\mathrm{N} / \mathrm{A}$} \\
\hline Vi,incipient velocity, m/s & 2.065 & 2.109 & \multicolumn{2}{|l|}{ ERR } \\
\hline Vr, velocity ratio & 0.230 & 0.524 & \multicolumn{2}{|l|}{ ERR } \\
\hline K4, armor factor & 0.69 & 0.89 & \multicolumn{2}{|l|}{$\mathrm{N} / \mathrm{A}$} \\
\hline ys, scour depth, (K4 applicable) ft & $=15.00$ & 22.80 & \multicolumn{2}{|l|}{ ERR } \\
\hline ys, scour depth, (K4 not applied) ft & $=E R R$ & ERR & \multicolumn{2}{|l|}{ ERR } \\
\hline \multicolumn{5}{|c|}{$\begin{array}{l}\text { D50=0.692 }(\mathrm{K} * \mathrm{~V}) \wedge 2 /(\mathrm{Ss}-1) * 2 * \mathrm{~g} \\
\text { (Richardson and others, } 1995, \mathrm{p} .115 \text {, eq. } 83) \\
\text { Pier-shape coefficient (K), round nose, } 1.5 \text {; square nose, } 1.7 \\
\text { Characteristic avg. channel velocity, } \mathrm{V},(\mathrm{Q} / \mathrm{A}): \\
\text { (Mult. by } 0.9 \text { for bankward piers in a straight, uniform reach, } \\
\text { up to } 1.7 \text { for a pier in main current of flow around a bend) }\end{array}$} \\
\hline \multicolumn{2}{|l|}{ Pier 1} & Q100 & \\
\hline \multicolumn{2}{|l|}{ K, pier shape coeff. } & 1.5 & \multicolumn{2}{|c|}{ Q500 $\quad$ Qother } \\
\hline V, char. aver. velocity, ft/s & & 8.1 & 11.12 & 0 \\
\hline D50, median stone diameter, ft & & 0.96 & 1.81 & 0.00 \\
\hline Pier 2 & & & & \\
\hline K, pier shape coeff. & & 1.5 & 1.5 & 0 \\
\hline V, char. aver. velocity, ft/s & & 8.1 & 11.12 & 0 \\
\hline D50, median stone diam & & 0.96 & 1.81 & 0.00 \\
\hline
\end{tabular}


